\title{
On the spreading of one fluid over another
}

\author{
(Continuation and end) (*)
}

\author{
Bх M.B. ABBOTT \\ RESEARGH ENGINEER \\ COASTAL ENGINEERING LABORATORX, TEGHNICAL UNIVERSITY OF DENMARK
}

(French text, p. 847)

\begin{abstract}
Although particularly concerned with the spreading of oil over water, this paper 'also deals with the general problem of determining the nature and rate of spreading of any one incompressible fluid over another of greater density. It is in three parts.
\end{abstract}

\section{PART I}

The two fluid layers are treated as the components of a coupled system and a general equation is derived for their characteristics. The number of degrees of freedom of such a fluid system is redefined and related to the capacities for wave propagation of the system. The number of characteristics in a coupled system is then related to the number of fluid components in the system, and the two types of uncoupled component are identified. It is shown that the effect of coupling is to separate the characteristics of the components and that, when the lower fuid is much deeper than the surface fluid, the surface fluid behaves as an uncoupled system. The Riemann invariants and "quasi-invariants" of this uncoupled system are investigated and a means of solving problems of rectilinear spreading obtained.

\section{PART II}

The analogous problem of a bursting dam is considered and a "wave front" introduced to better explain the behaviour observed experimentally. The front of the surface fluid is then studied in a similar manner and the relations obtaining at the front are again verified by experiment.

\section{PART III}

The equations and characteristics obtaining in radial flow are derived. The characteristics are identical with those arising in rectilinear flow, but their invariant properties differ. These properties are investigated and a procedure developed whereby problems involving the radial flow of one fluid over another may be solved.

In conclusion the present work is compared with previous studies on the same subject.

\section{PART II}

\section{THE WAVE FRONT}

So far the flow of one fluid over another has been considered only for the case of an established flow. Since, however, the upper fluid spreads at only a finite rate, there will generally exist a region of the lower fluid which is, as yet, uncovered by the upper fluid $\left(^{* *}\right)$. The line of

${ }^{\star}{ }^{\star}$ See La Houille Blanche, No.5-1961, page 622.

(**) This is not to say, of course, that the whole of this uncovered region is unaffected by the discharge of the upper fluid. The rapidly moving energy regimens in the lower fluid will announce the presence of the upper fluid some time before it actually arrives. demarcation between this region and the region which is covered by the upper fluid will be called the "fluid front." The particular features of this front will be associated, through the appropriate characteristics, with the entire flow, and thus the above description of conditions in the body of the fluid is incomplete without further knowledge of conditions at the fluid front. These conditions are discussed in the present section, first in terms of the analogous problem of the wave front engendered by the sudden failure of a dam, and then in terms of the theories of 
hydraulic stability, as originally proposed by Rossby and Craya (Ref. 5).

\section{The wave front formed after the sudden failure of a dam}

The equations of motion and continuity of the uncoupled surface system considered above become identical to the equations of long wave motion if the term $(1-\lambda) g h$ is replaced by the term $g h$ (e.g. Ref. 14, Ref. 2 p. 255). On the basis of the same substitution, the characteristics and Riemann invariants will also become identical. Physically the situation following the release of one fluid over another will be seen to correspond, with this one adjustment, to the situation following the release of a fluid over a dry bed, i.e. to the situation which arises following the sudden failure of a dam.

According to the theory of fluid behaviour following the failure of a dam, as originally proposed by St. Venant (Ref. 4 p. 755), the equations governing the motion of long waves are assumed to hold over the entire range of flow, including the fluid front, for all times following the failure. The physical characteristics corresponding to this assumption are shown in Fig. $4 a$ ('see, for example, Ref. 10 p. 333). If the slope of the initial downstream characteristic relative to the time axis be denoted by $\Phi_{u}$, so that

$$
\Phi_{u}=-\left(g h_{u}\right)^{1 / 2}
$$

then, by following any $\mathrm{C}_{+}$characteristic, on arriving at the $i^{\prime}$ th $C_{-}$characteristic the conditions are found to be given by

$$
u_{i}+2\left(g h_{i}\right)^{1 / 2}=2\left(g h_{u}\right)^{1 / 3}
$$

or

$$
u_{i}+2\left(g h_{i}\right)^{1 / 3}=-2 \Phi_{u}
$$

Now let the angle, also measured anticlock-

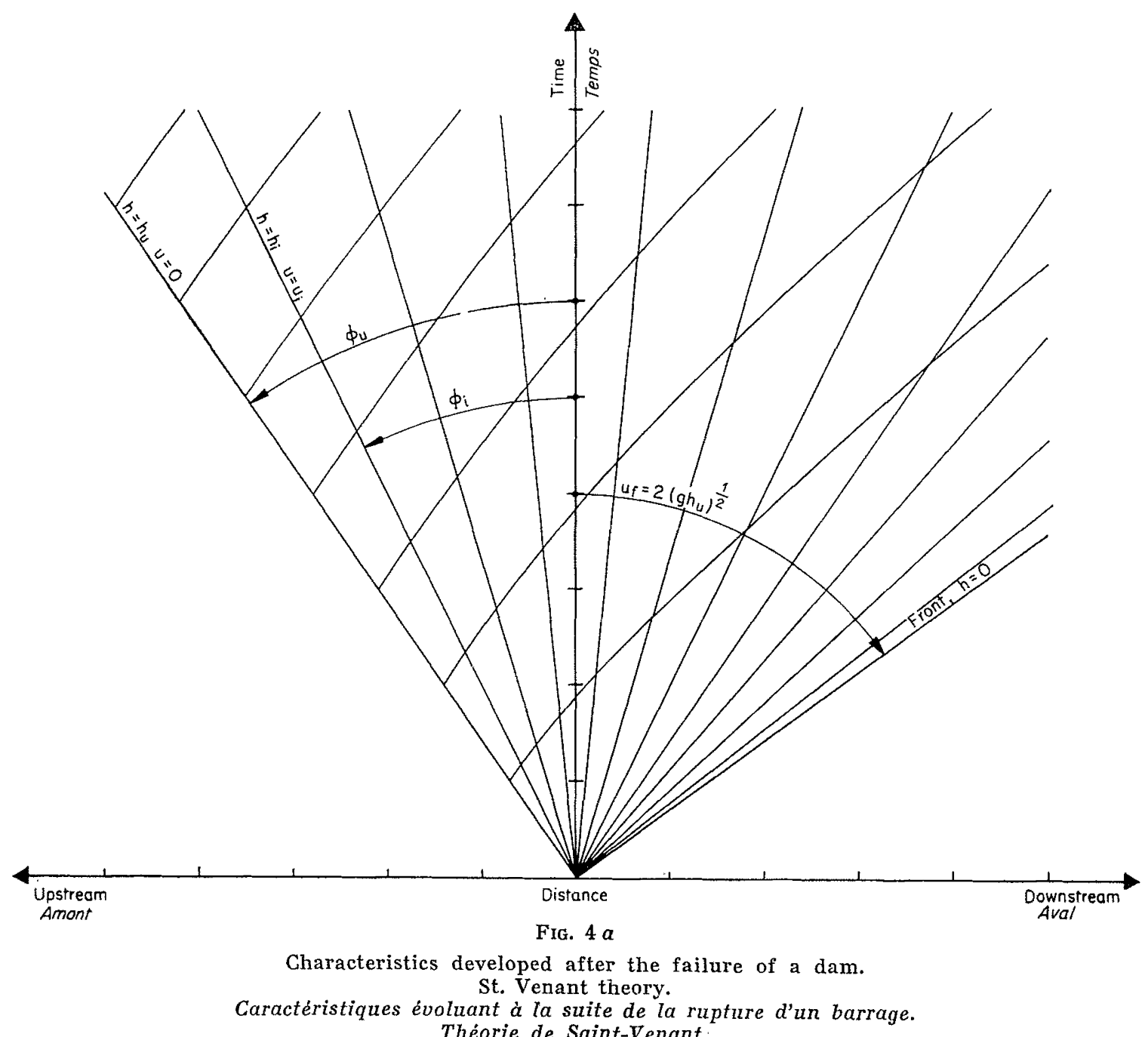




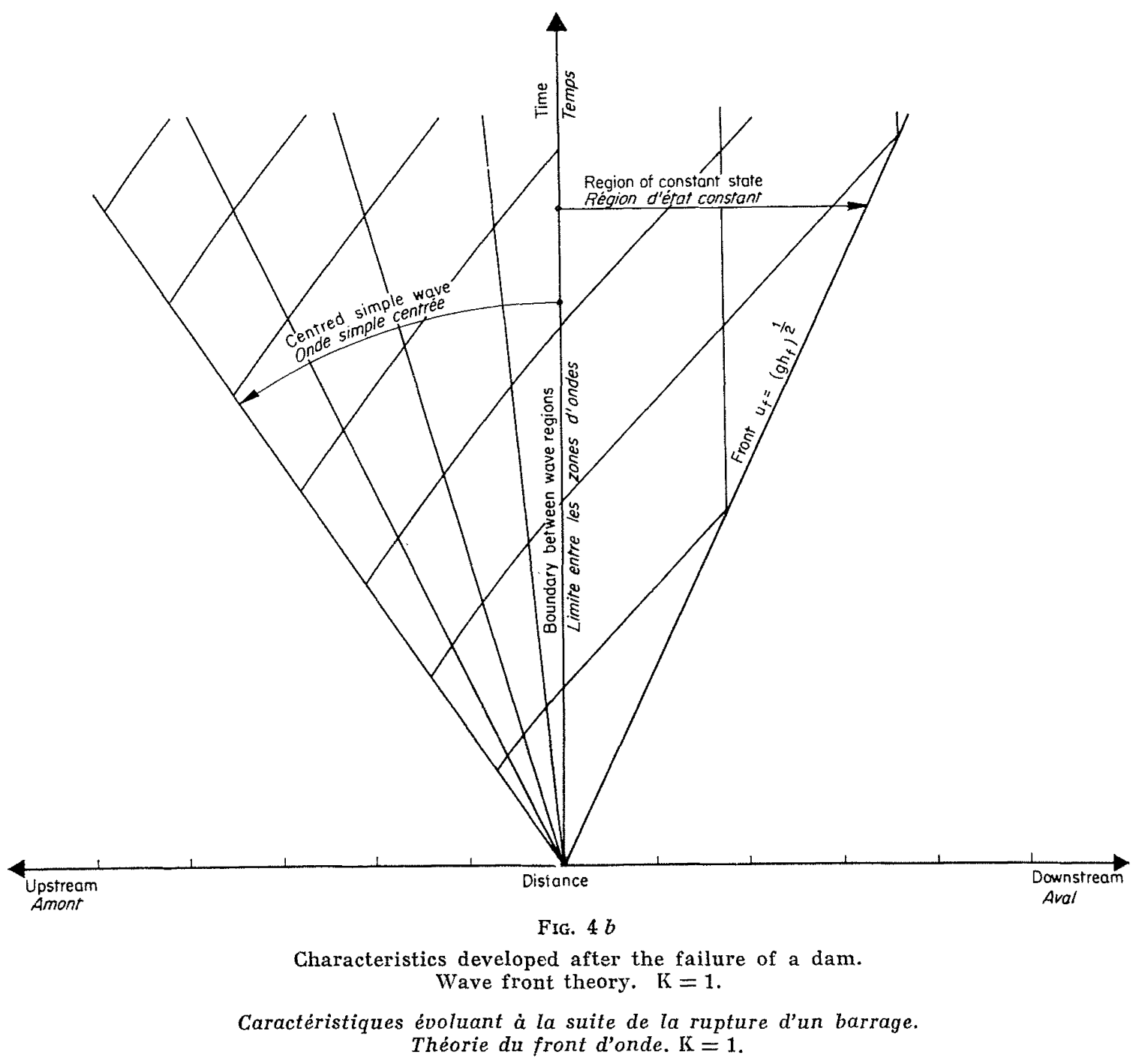

wise, between the time axis and the $i$ th $\mathrm{C}_{-}$characteristic, be denoted by $\Phi_{i}$ (Fig. $4 a$ ), so that

$$
u_{i}-\left(g h_{i}\right)^{1 / 2}=\Phi_{i}
$$

Then, from (13) and (14), it follows that

$$
\begin{gathered}
h_{i}=\frac{\left(2 \Phi_{u}-\Phi_{i}\right)^{2}}{9 g} \\
u_{i}=\frac{-2 \Phi_{u}+2 \Phi_{i}}{3} \\
u_{i}+\left(g h_{i}\right)^{3 / 2}=\frac{-4 \Phi_{u}+\Phi_{i}}{3}
\end{gathered}
$$

From (15) it is seen that, at the fluid front, where $h_{i}=0$,

$$
\begin{gathered}
\Phi_{i}=-2 \Phi_{u}=+2\left(g h_{u}\right)^{1 / 2} \\
u_{i}=-\frac{6 \Phi_{u}}{3}=+2\left(g h_{u}\right)^{3 / 2} \\
u_{i}+\left(g h_{i}\right)^{3 / 2}=-\frac{6 \Phi_{u}}{3}=+2\left(g h_{u}\right)^{3 / 2}
\end{gathered}
$$

Thus the front is composed of the characteristic envelope formed by the coincidence of the $\mathrm{C}_{+}$and $\mathrm{C}_{-}$characteristics, so that the front velocity, $u_{f}$, is identical with the wave celerity.

The above procedure is open to several objections, not the least of which is that it gives results which are at considerable variance with observations near the wave front. The nature of this disagreement is illustrated, in Fig. 5 by the well-known results of Schoklitsh (Ref. 4, p. 755). These results, together with more general observations, suggest that in practice the wave front presents the aspect of a veritable "wall" of water propagating over the dry bed. For the purposes of this study, it is not necessary to enquire into the actual structure of such a "wall-like" wave front, but only to determine the relations, if any, which it imposes between the front height, $h_{f}$, and the front velocity, $u_{f}$.

For dimensional compatibility a front relation is suggested of the form

$$
u_{f}=k\left(g h_{f}\right)^{3 / 2}
$$




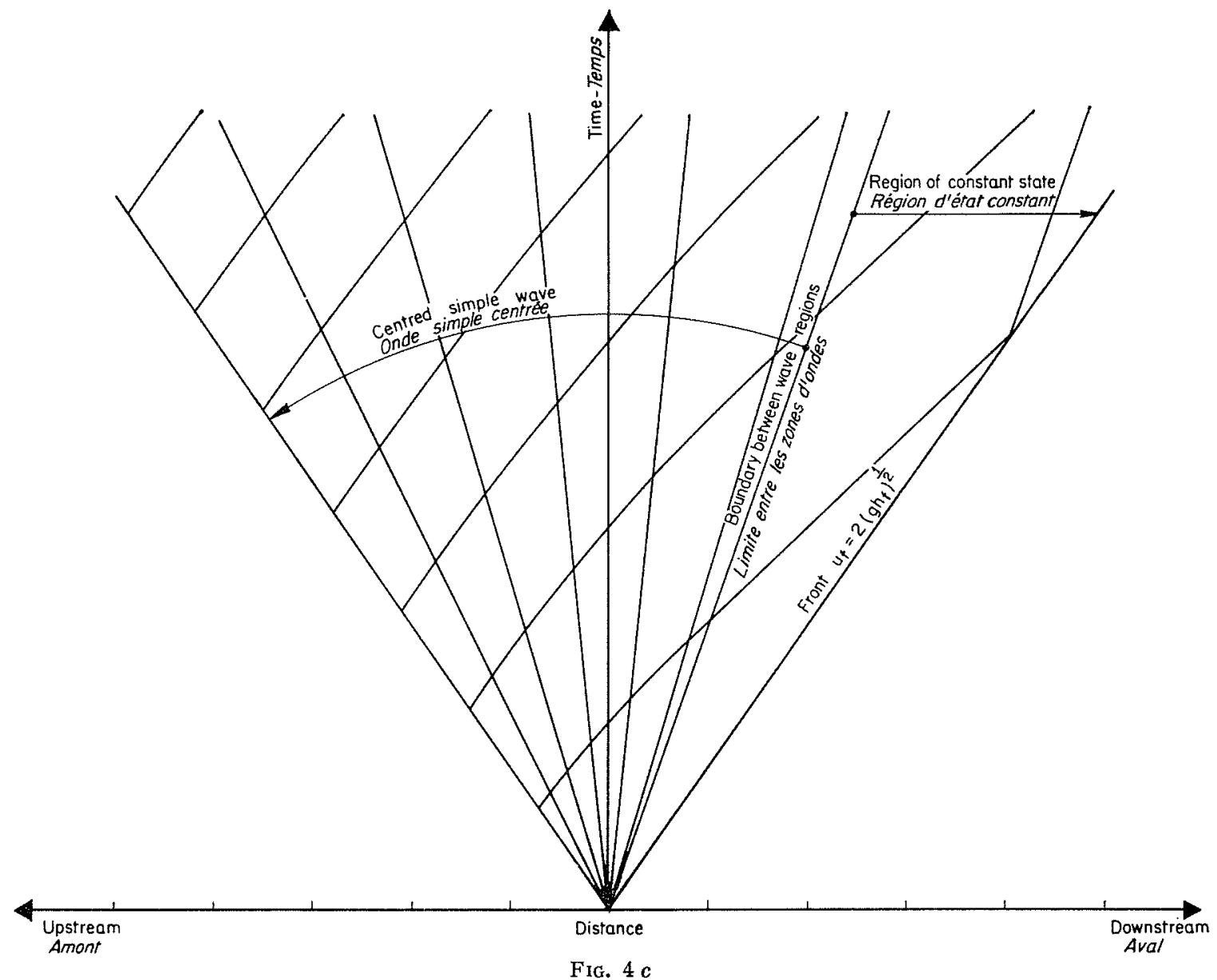

Characteristics developed after the failure of a dam. Wave front theory. $K=2$.

Caractéristiques évoluant à la suite de la rupture d'un barrage. Théorie du front d'onde. $\mathrm{K}=2$.

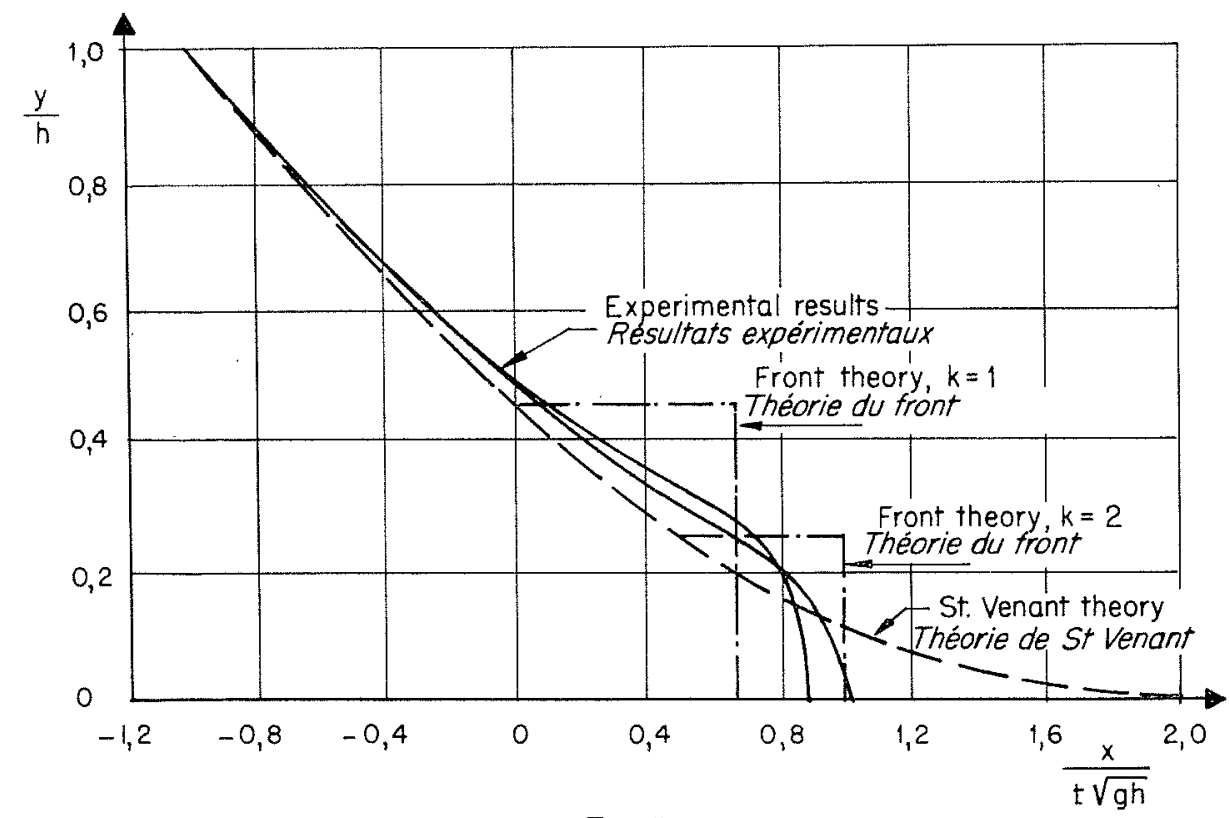

Fig. 5

Reproduced from "Engineering Hydraulics", General Editor: Hunter Rouse, 1950 Edn.

D'après "Engineering Hydraulics"; Directeur de l'édition: Hunter Rouse, édition 1950.

Solid lines on graph are observed levels.

Les traits continus du graphique sont les niveaux observés. 


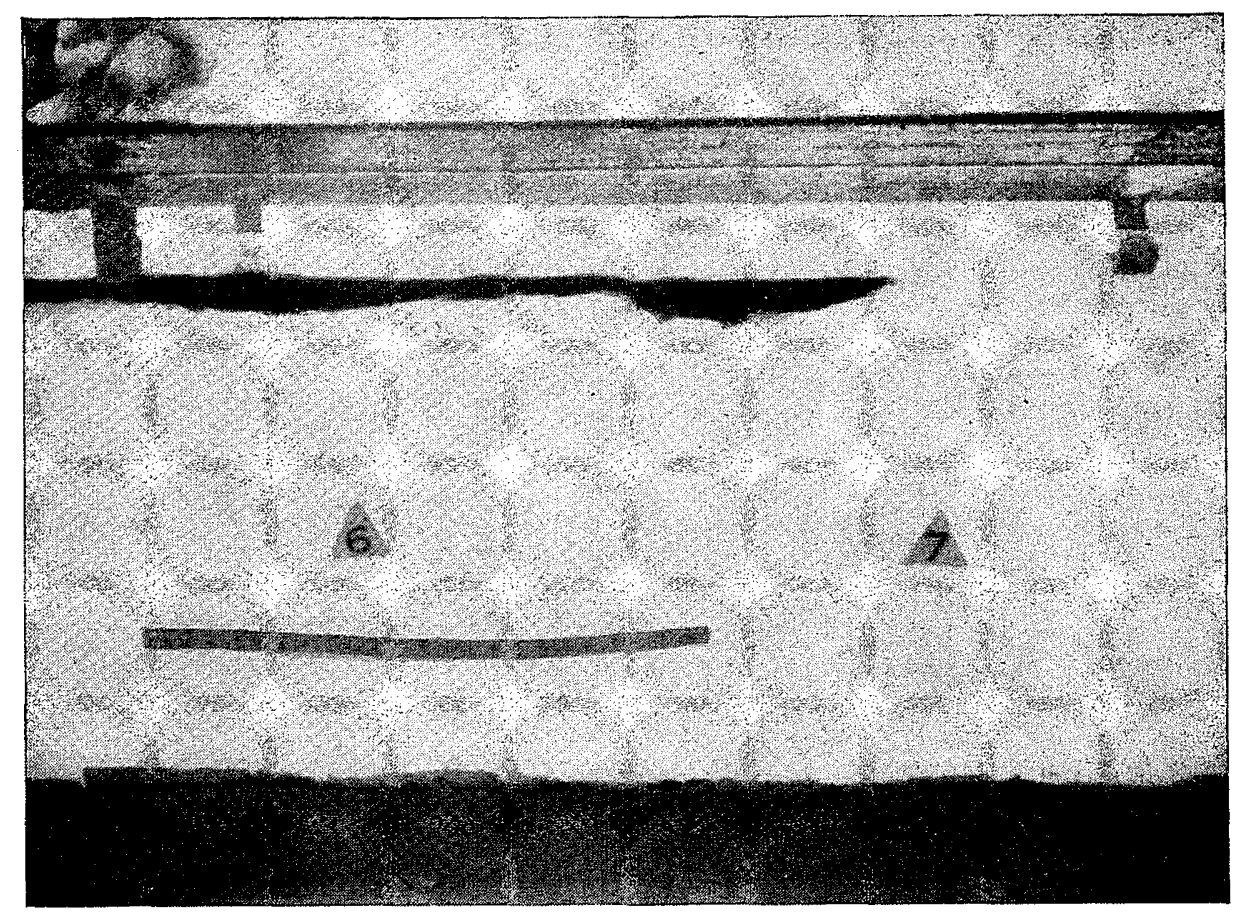

Prate I

Oil lying over flowing water in a straight uniform channel, Showing a typical "arrow-head" shaped front.

Huile étalée sur de l'eau s'écoulant dans un canal rectiligne et uniforme. On voit le front en forme de "pointe de flèche» caractéristique.

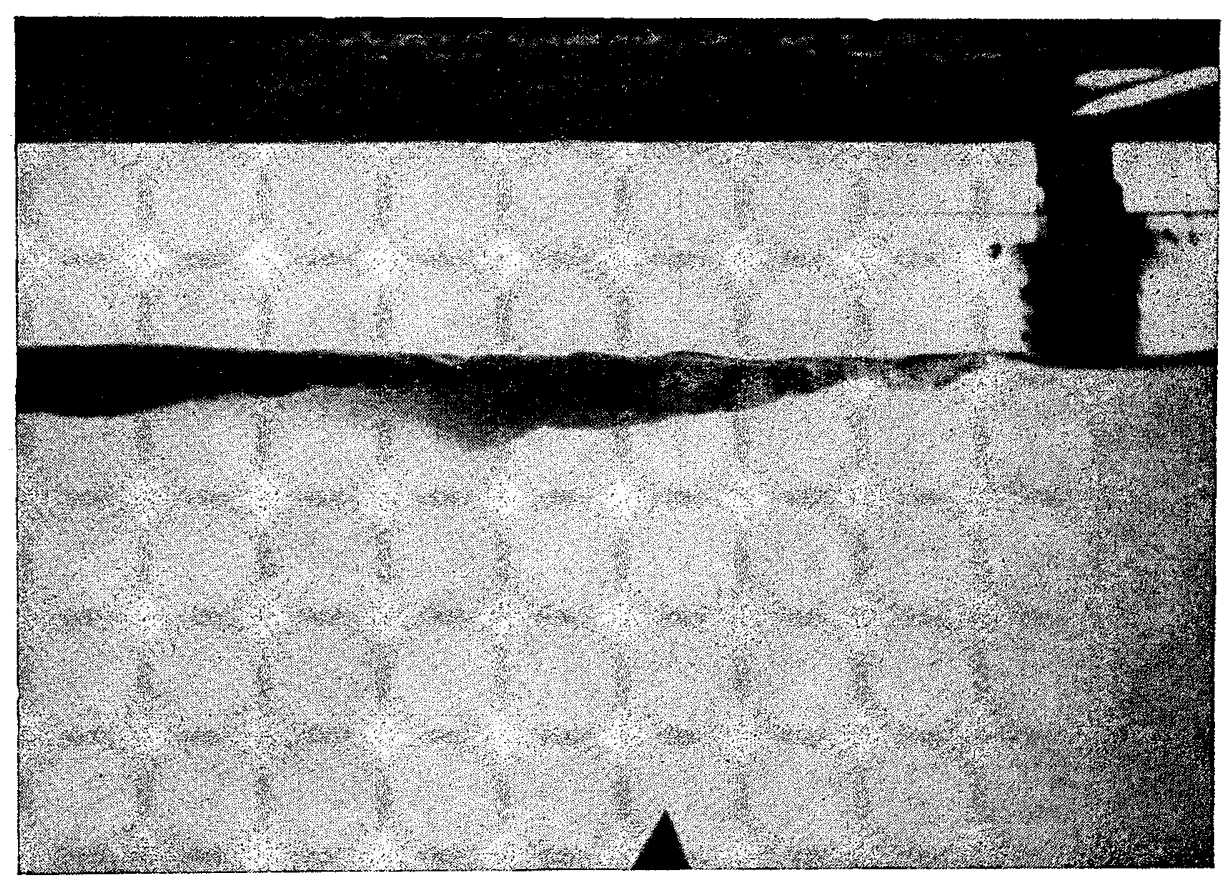

Plate II

Close-up of the oil front.

Vue rapprochée du front d'huile. 
Now it seems reasonable, from physical considerations, to associate such a wave front condition with the normal conditions of instability in a homogeneous fluid, i.e. with the coincidence of the fluid velocity with the natural celerity of energy propagation through the fluid. On the basis of this assumption $k$ takes a value of unity (see also Ref. 6, p. 392). The flow conditions following from such an assumption may again be expressed in terms of physical characteristics subtending angles $\Phi_{i}$, with an initial upstream characteristic at $\Phi_{u}$ (Fig. $4 \mathrm{~b}$ ). In this case, however, the front condition, which holds for all $x>0$ (Fig. 6) gives

$$
\begin{aligned}
\Phi_{i} & =u_{f}-\left(g h_{f}\right)^{1 / 2} \\
& =0,
\end{aligned}
$$

for all characteristics intersecting the front. Thus the line $x=0$ forms a boundary to the simple centred wave region of the St. Venant theory. To the left of this boundary (Fig. $4 b$ ), along the $\mathrm{C}_{+}$characteristics

$$
u_{i}+2\left(g h_{i}\right)^{3 / 2}=u_{f}+2\left(g h_{f}\right)^{1 / 2},
$$

while along the $\mathrm{C}_{-}$characteristics

$$
u_{i}-2\left(g h_{i}\right)^{1 / 2}=u_{f}-2\left(g h_{f}\right)^{1 / 2}
$$

Thus $u_{i}=u_{f}$ and $h_{i}=h_{f}$ throughout the flow region $x>0$, so that to the left of the original dam there exists a region of constant state, where the flow quantities remain at their critical values.

The results following from the assumption that $k=1$ are shown in Fig. 5, where it is seen that, although the agreement with the experimental results is better than that given by the St Venant theory, it is still not entirely satisfactory. In fact, the experimental results are much better simulated when $k=2$ (Fig. .5), (Ref. 4 p. 756). The physical characteristics

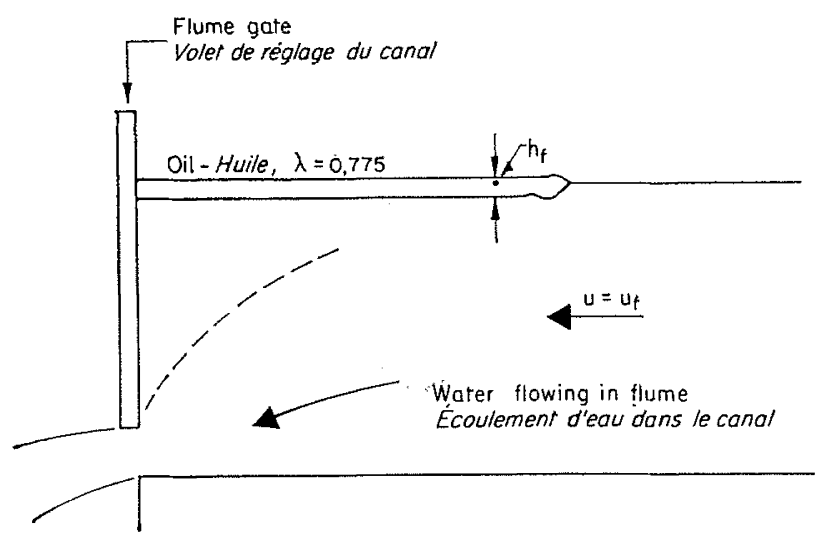

Fig. 6

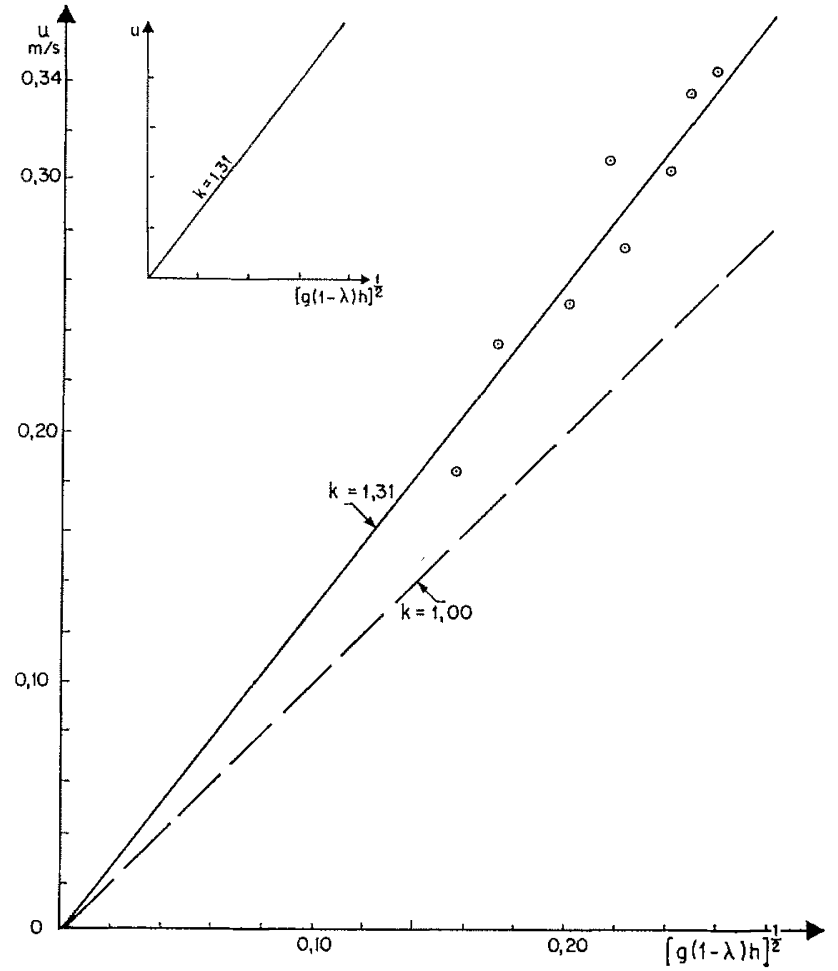

FIG. 7

appertaining to this condition are shown in Fig. $4 c$. It may be noted that, whatever the value of $k$, the assumption of a wave front condition of the form of (18) gives rise to a region of constant state behind the front, where the flow quantities remain at their critical values. Moreover, since the ordinate $x=0$ is always characteristic, the rate of fluid flow across that ordinate is always constant.

From the point of view of agreement with experimental evidence, it thus seems that neither the "envelope" front of the St. Venant theory, nor the front condition dictated by elementary stability conditions, obtains in practice, and that instead an intermediate type of condition gives the best description of reality.

\section{The wave front formed in a fluid with density stratification}

The oil front formed when oil is released over water is illustrated in plates (I) and (II). This oil front is seen to possess a distinct "head," at which the flow conditions in the oil are effectively established, and is thus similar in form to the fluid front which occurs after the sudden failure of a dam. This similarity, together with the similarity which exists between the equa- 


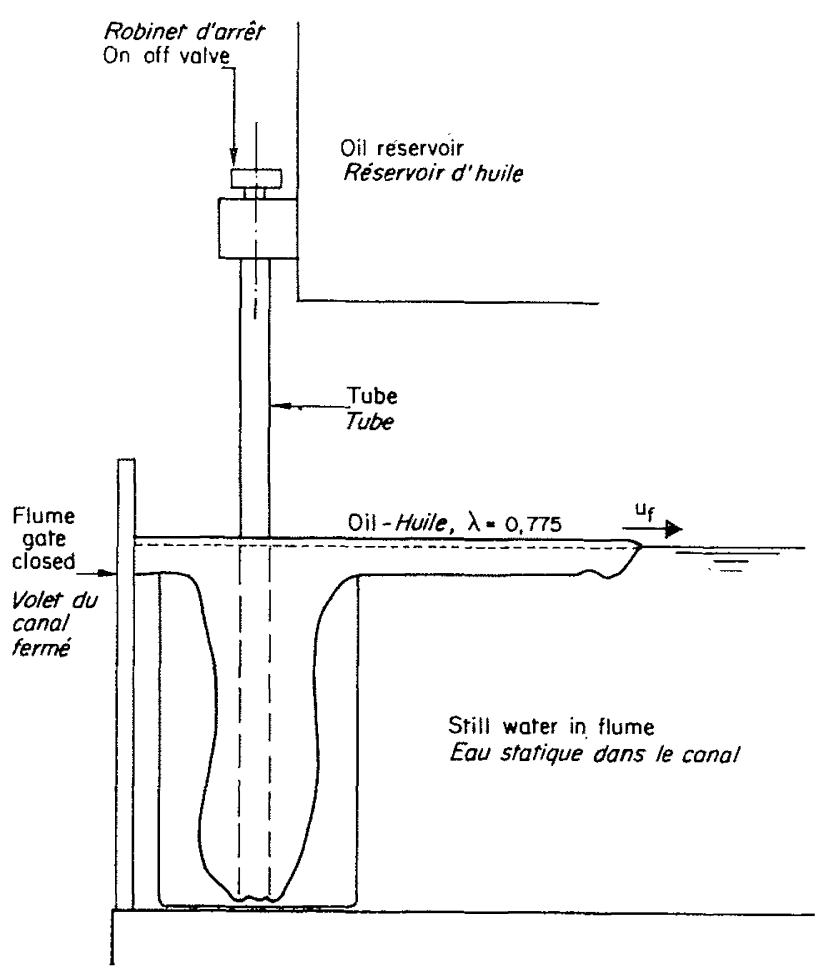

Fig. 8

tions of motion in the two cases, suggests that the front condition should take the form

$$
u_{f}=k\left\{g(1-\lambda) h_{f}\right\}^{\gamma^{\prime}}
$$

This, however, is identical in form to the stability condition proposed, by Rossby and Craya, in the case of one fluid flowing over another (Ref. 5 p. 15, p. 28). These authors found, from both energy and momentum considerations that the flow conditions in a shallow surface fluid become critical when $k=1$. However, the above investigation of fluid flow following the failure of a dam, indicates that such a stability condition cannot be simply equated to a front condition, and that it is necessary to determine the value of $k$ experimentally. Accordingly two series of experiments have been devised to determine the value of $k$.

In the first series of experiments devised to investigate the front condition, water was passed down a straight uniform flume, so that paraffin oil $(\lambda=0.775)$ floating on the water surface, was held against the flume gate (Fig. 6). As the water velocity was increased so, through the front condition, the oil layer became shorter and thicker. The relation between the water velocity and the oil thickness could then be used to determine the value of $k$ directly.

The results obtained from these experiments are shown plotted in Fig. 7, where it is seen that a value of $k=1.31$ appears to best satisfy the observations. These results were, however, subject to considerable errors, due to the effects of turbulence (e.g. plates (I) and (II), so that they could not be considered entirely conclusive. Accordingly another, and independent series of experiments was carried out.

In the second series of experiments the same type of paraffin oil was introduced at a uniform rate into still water, at one end of a straight uniform flume, the other end of the flume being sealed with a vertical wall (Fig. 8). The oil wave travelled down to this wall and was there reflected, the progress of its front being recorded throughout.

The results of these tests are shown in Fig. 9, where also the experimental results are compared with the results of a calculation, based on a value of $k=1$. The constant state part of this calculated flow pattern (region I in Fig. 9), is identical with that given, for $k=1$, in the case of the sudden failure of a dam, since here again the source is steady and the critical state corresponds to space stationary $\mathrm{C}_{-}$characteristics. This region is followed by a centred simple wave, which corresponds to the sudden cessation of flow, and which is illustrated as region II in Fig. 9. The centred wave is in turn followed by another region of constant state (region III) in which the velocity is of course zero. For the calculation of the reflected wave it is assumed throughout that the potential energy of the reflected wave is exactly balanced by the

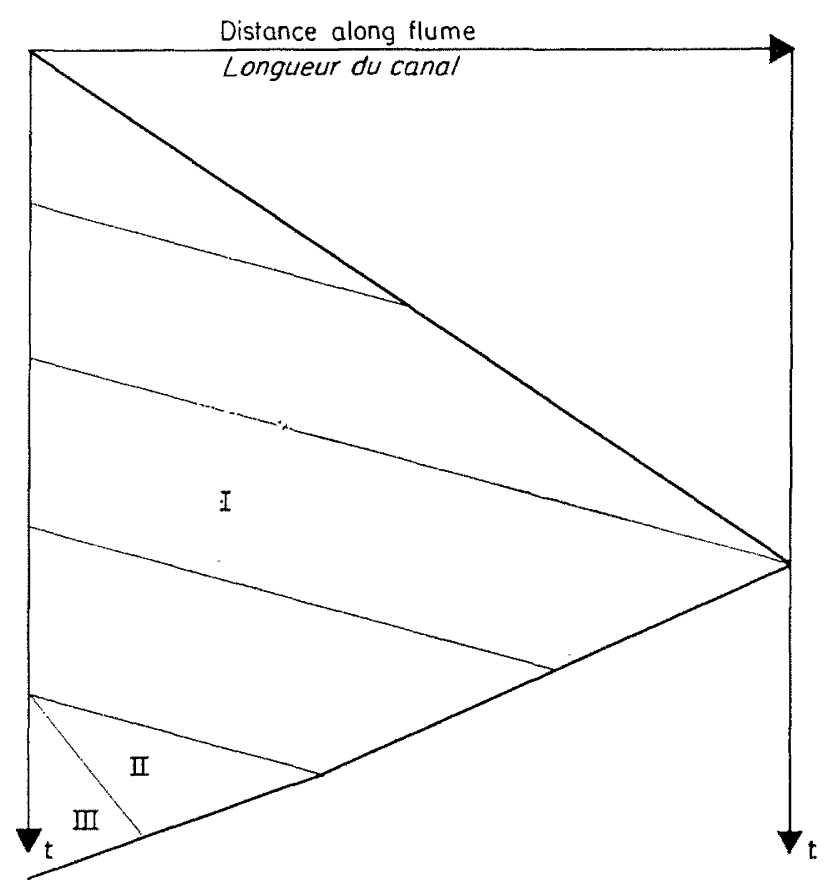

Fig. 9 


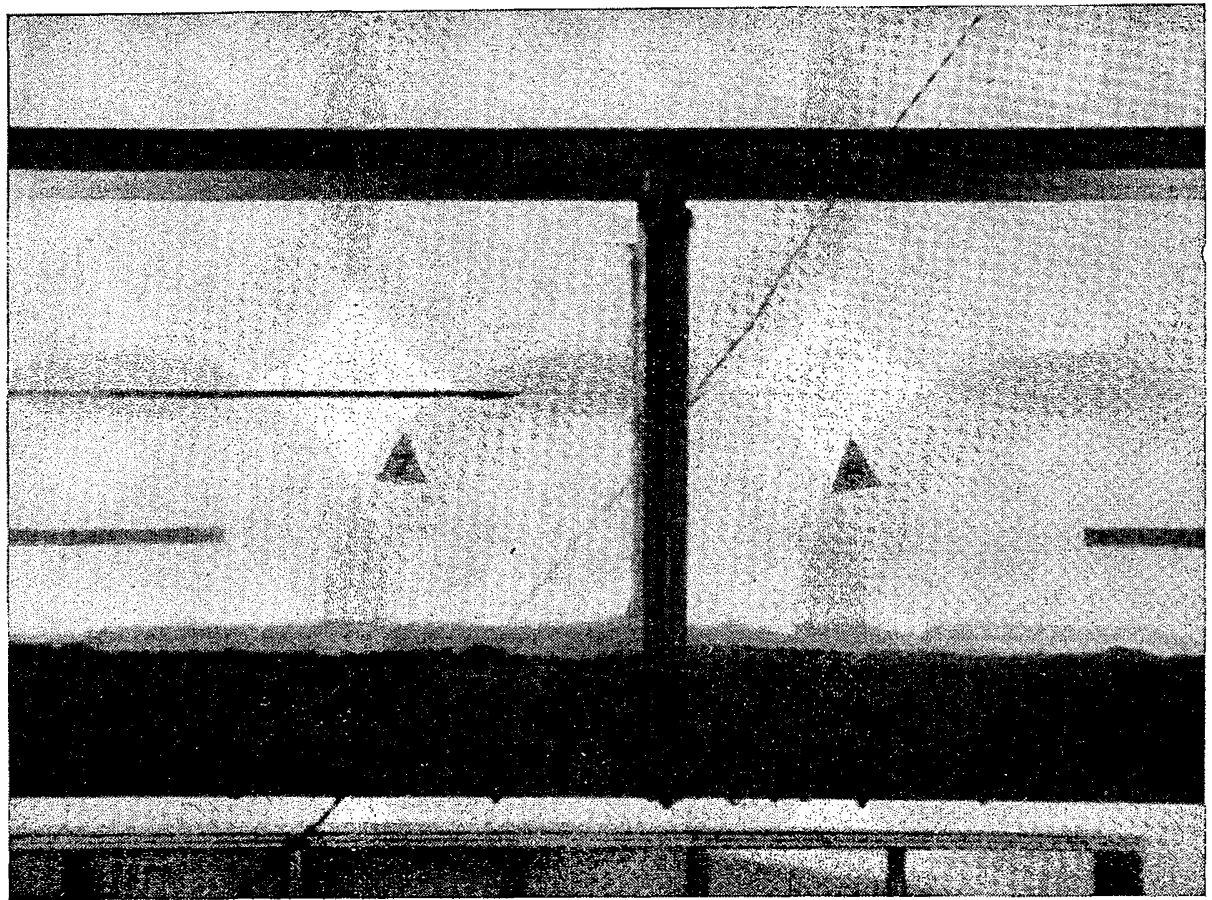

Plate III

Incident oil wave travelling from left to right along a straight uniform channel, again showing the arrow-head shaped front.

Onde d'huile incidente, se déplaçant de gauche à droite

le long d'un canal rectiligne et uniforme.

On voit ici également le front en «pointe de flèche».

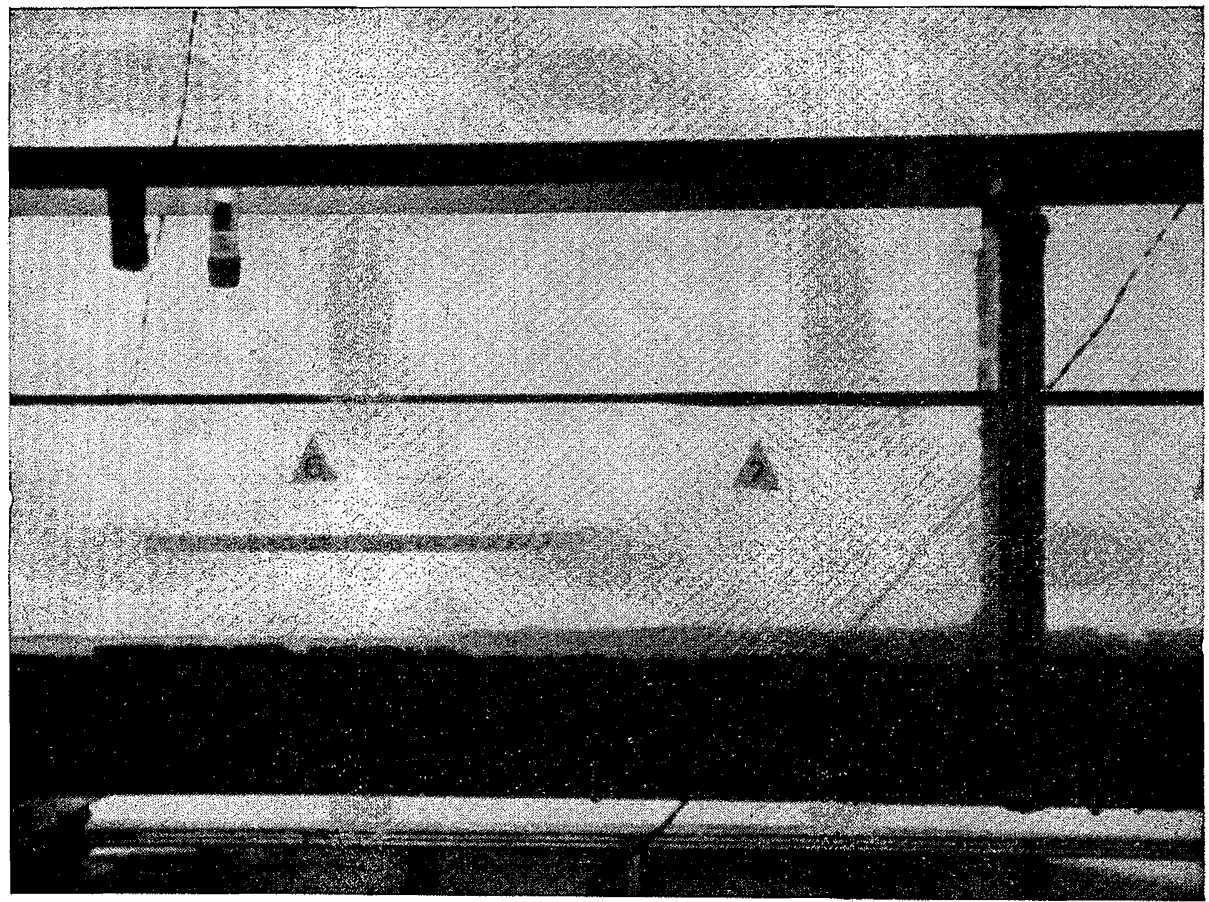

Plate IV

Reflected oil wave travelling from right to left along the same channel.

Onde d'huile réfléchie, se déplaçant de droite à gauche, dans le mếme canal. 


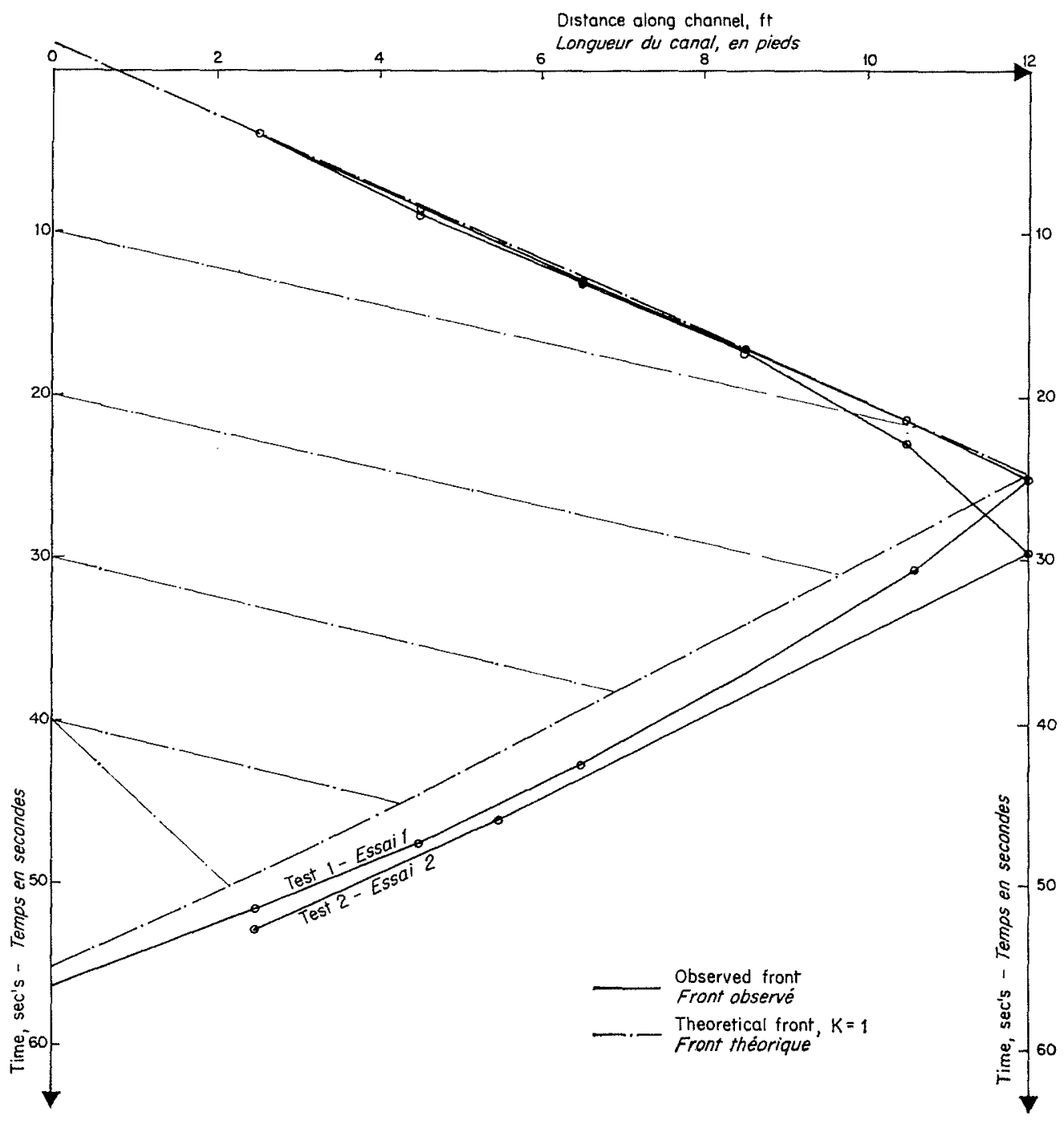

FIG. $9 a$

Comparison of observed and theoretical oil fronts in a straight uniform channel.

Comparaison entre les fronts d'huile observés et théoriques dans un canal rectiligne uniforme.

kinetic energy flux of the incident flow relative to the reflected wave front (Ref. 10 p. 314, Ref. 11 p. 398).

Referring to Fig. 9 it is seen that the value of $k=1$ gives a satisfactory agreement with observation for the incident wave. The reflected wave is not so well simulated, but even in this case the maximum error in distance traversed is within the limits of experimental accuracy. It is easily seen that values of $k$ other than unity give less satisfactory agreement, so that this series of experiments suggests a value of $k=1$.

The difference in the value of $k$, as obtained from the two series of experiments, can be attributed to the differences in flow conditions in these experiments. Plates III and IV illustrate the oil front in the second series of experiments and, comparing these with plates I and II, it is seen that, although the same arrow head shaped front occurs in both series of experiments, the front conditions otherwise differ quite considerably. Taking into account the differences in the level of turbulence etc., the second series of experiments would appear to best represent prototype conditions, so that $k$ can be taken as approximately unity. In this case, then, the stability condition and the front condition do coincide, and

$$
u_{f}=\left\{g(1-\lambda) h_{f}\right\}^{3 / 2}
$$

It should be added, however, that the experiments described above were carried out over a necessarily limited range of values of the flow quantities, and further tests would appear to be necessary before (20) can be stated with certainty. 


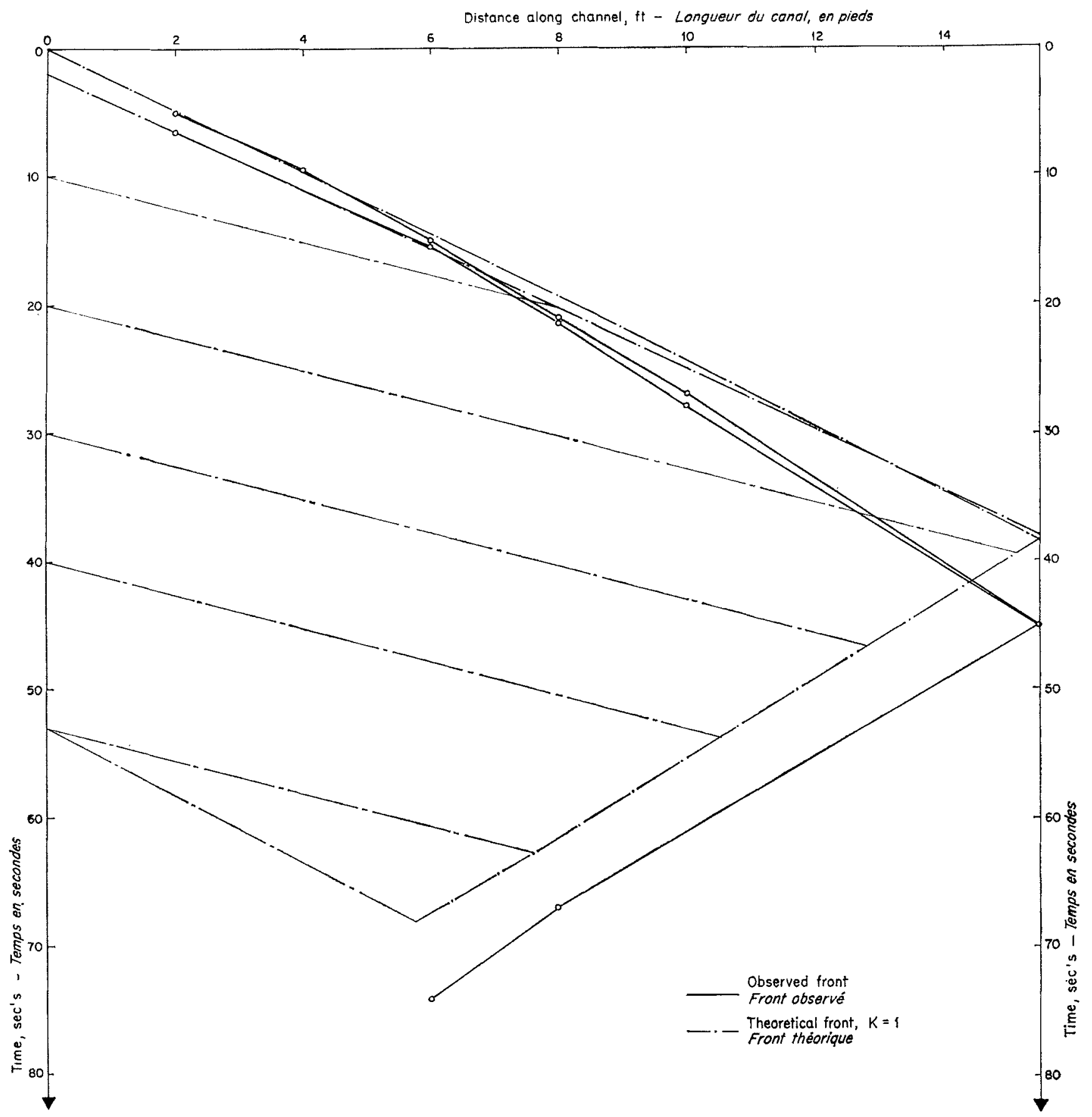

Fia. $9 b$

Comparison of observed and theoretical oil fronts in a straight uniform channel.

Comparaison entre les fronts d'huile observés et théoriques. 


\section{DISCHARGE OF OIL INTO STILL WATER RADIAL FLOW}

In this study of the two-dimensional spreading of one fluid over another, it will be assumed that the surface fluid diverges uniformly from a point source. If in practice the source is located at a wall (as corresponds to the case of initial spillage from the side of a tanker) then the flow is effectively confined to a half plane. However, this half plane case, with, say, a source $q$, is readily seen to correspond to a whole plane case in which the source strength is $2 q$. In practice the flow from a damaged tanker will start as a half plane flow, but will come more and more to resemble a whole plane flow as the oil patch passes around the stem and stern of the vessel (Fig. 10). This picture becomes more complicated in the presence of a tidal stream flowing past an anchored vessel, for then the oil wave will be distorted by the

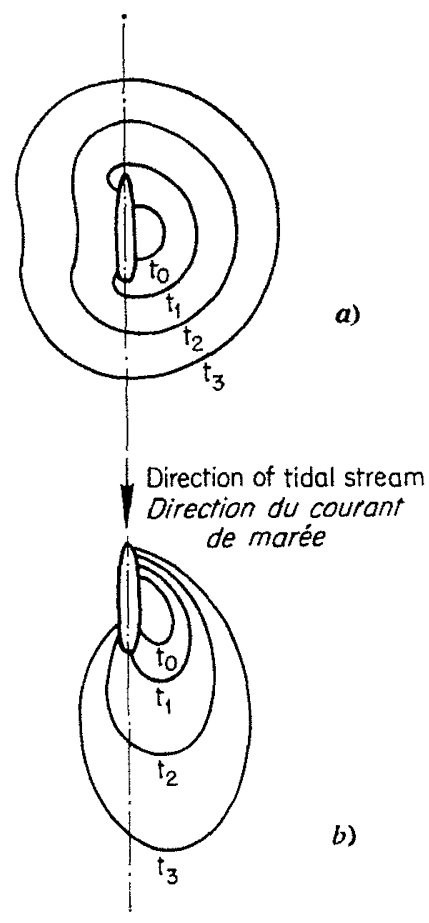

Fig. 10

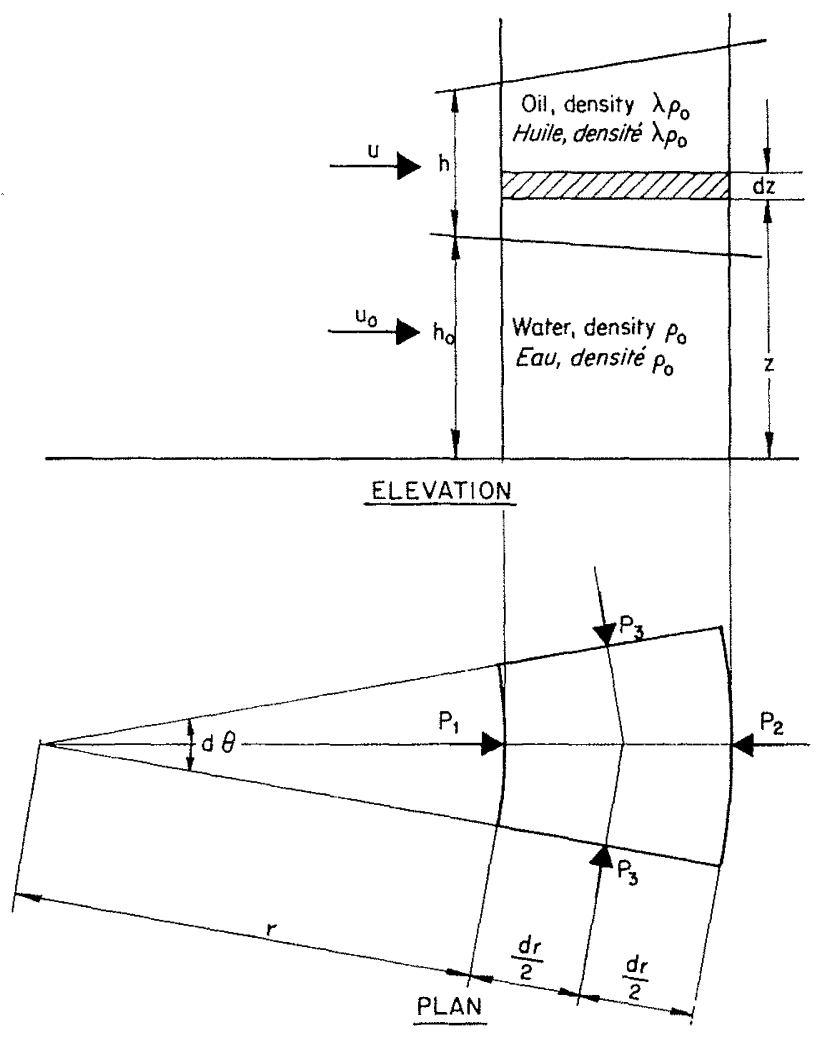

FIG. 11

stream, and the radial approximation can no longer be justified (Fig. $10 \mathrm{~b}$ ).

In this section the radial flow of oil over water will be described in terms of two independent variables. These will be the distance from the oil source, $r$, and the time elapsing from the commencement of discharge, $t$. For consistency with the one-dimensional case, the dependent variables will again be taken as the depths, $h$ and $h_{0}$, and velocities, $u$ and $u_{0}$, although the velocities will now be measured radially from the source. That these variables are not entirely satisfactory can be easily seen by observing that, at the source, the oil velocity $u$ becomes infinite. The consequences of this will appear later. 


\section{The equations and characteristics for radial propagation}

Fig. 11 shows the section and plan of a segment of the oil and water system. The pressure, $p$, acting on an element of thickness, $d z$, located in the oil at any height, $z$, is again given by

$$
p=p(z, r)=\lambda \rho_{0} g\left(h_{0}+h-z\right)
$$

so that, in the oil

$$
\frac{\partial p}{\partial r}=\lambda_{\rho_{0}} g\left(\frac{\partial h_{0}}{\partial r}+\frac{\partial h}{\partial r}\right)
$$

The equation of motion for the element when it is situated in the oil can be determined by considering the forces acting upon it. These are (Fig. 11):

$$
\begin{aligned}
& \mathbf{P}_{1}=\lambda_{\rho_{0}} g\left(h+h_{0}-z\right)+\left(\frac{\partial h_{0}}{\partial r} \frac{d r}{2}+\frac{\partial h}{\partial r} \frac{d r}{2}\right)\left(r+\frac{d r}{2}\right) d z d \theta \\
& \mathrm{P}_{2}=\lambda \rho_{0} g\left(h+h_{0}-z\right)-\left(\frac{\partial h_{0}}{\partial r} \cdot \frac{d r}{2}+\frac{\partial h}{\partial r} \frac{d r}{2}\right) \quad\left(r-\frac{d r}{2}\right) d z d \theta \\
& \mathrm{P}_{3}=\lambda \wp_{0} g\left(h+h_{0}-z\right) d r d z
\end{aligned}
$$

Then the total radial force, $P$, is given by

$$
\mathrm{P}=\lambda \rho_{0} g-r\left(\frac{\partial h_{0}}{\partial r}+\frac{\partial h}{\partial r}\right) d r d z d \theta
$$

The rate of change of momentum is

$$
\frac{\partial \mathbf{M}}{\partial t}=\lambda \rho_{0}\left\{\frac{\partial u}{\partial t}+u \frac{\partial u}{\partial r}\right\} r d r d z d \theta
$$

so. that

$$
\frac{\partial u}{\partial t}+u \frac{\partial u}{\partial r}+g\left(\frac{\partial h_{0}}{\partial r}+\frac{\partial h}{\partial r}\right)=0
$$

Considering now the equation of continuity, it may be seen that the nett rate of flow, $d q$, into an element of thickness $h$ is given by

$$
d q=u h r d \theta-\left\{u h r d \theta+\frac{\partial}{\partial r}(u h r d \theta) d r\right\}=\left\{u h+h r \frac{\partial u}{\partial r}+u r r-\frac{\partial h}{\partial r}\right\} d r d \theta
$$

The rate of change of volume of such an element is

$$
d q=\frac{\partial h}{\partial t} r d r d \theta
$$

Then equating the nett rate of inflow to the rate of change of volume of the element gives

$$
\frac{\partial h}{\partial t}+h \frac{\partial u}{\partial r}+u \frac{\partial h}{\partial r}+\frac{u h}{r}=0
$$

The equations of motion and continuity may be found in the same way for the case when the fluid elements is situated in the water. These equations are then

$$
\begin{aligned}
& \frac{\partial u_{0}}{\partial t}+u_{0} \frac{\partial u_{0}}{\partial r}+g\left(\frac{\partial h_{0}}{\partial r}+\frac{\partial h}{\partial r}\right)=0 \\
& \partial h_{0}+h_{0} \frac{\partial u_{0}}{\partial r}+u_{0} \frac{\partial h_{0}}{\partial r}+\frac{u_{0} h_{0}}{r}=0
\end{aligned}
$$


Comparing equations (21) and (23) with equations (1) and (3), it may be seen that the equations of motion for radial flow and rectilinear flow have identical forms. This is due to the balancing of forces of type $\mathrm{P}_{3}$ by a residual force from $\mathrm{P}_{1}$ and $\mathrm{P}_{2}$. The equations are again coupled through the last terms of (21) and (23).

From equations (21) to (24) it will be apparent that the matrix form of these equations and their variations, is the same as the matrix of the rectilinear case, (5), except that - $(u h / r)$ and $-\left(u_{0} h_{0} / r\right)$ now appear in the right hand column vector. The condition defining the characteristics, and their corresponding invariant and quasi-invariant forms, is again that the $8 \times 9$ matrix formed from the coefficient matrix and the right hand column vector should be of rank 7 . Since $u h / r$ and $u_{0} h_{0} / r$ do not necessarily enter into the determinant defining the characteristics, these characteristics of radial flow may be defined in exactly the same way as in rectilinear flow. Thus

$$
\left[(u-\dot{x})^{2}-g h\right]\left[\left(u_{0}-\dot{x}\right)^{2}-g h_{0}\right]-\lambda g^{2} h h_{0}=0
$$

This correspondence of the characteristics in such apparently dissimilar flows follows from the wave properties of the phenomena, whereby the celerities of propagation at any point depend only on the flow quantities at that point. Thus, at any two points with identical flow quantities, the celerities will themselves be identical, even though the flow quantities be produced by one type of flow in one case, and a different type of flow in the other. The type of flow cannot, then, influence the expressions which define the characteristics. It follows from this that the characteristics of the uncoupled systems in radial flow may be defined in the same way as in rectilinear flow, and that the theorem on coupling will remain unchanged. The variational properties along the characteristics will be different, however, since the expressions which define these properties will now involve the additional terms $u h / r$ and $u_{0} h_{0} / r$.

The nature of the variations in the flow quantities along the characteristics may be determined in the same way as for rectilinear flow. Using the appropriate $8 \times 9$ matrix described above, one obtains the condition

$$
\left|\begin{array}{cccc}
(u-\dot{x}) & g & 0 & -\dot{u} \\
h & (u-\dot{x}) & 0 & -\left(\frac{u h}{r}+\dot{h}\right) \\
0 & g & \left(u_{0}-\dot{x}\right) & -\dot{u}_{0} \\
0 & 0 & h_{0} & -\left(\frac{u_{0} h_{0}}{r}+\dot{h_{0}}\right)
\end{array}\right|=0
$$

or

$$
\left.\left[(u-\dot{x})^{2}-g h\right]\left[\left(\frac{u_{0} h_{0}}{r}+\dot{h}_{0}\right)\left(u_{0}-\dot{x}\right)-h_{0} \dot{u}_{0}\right]-\lambda g h_{0}\left[h \dot{u}-\left(\frac{u h}{r}+\dot{h}\right)(u-\dot{x})\right]=0\right]
$$

Substituting $\dot{x}=u \pm\{g(1-\lambda) h\}^{1 / 2}$ in equation (25) and neglecting second order quantities (such as $u u_{0}$, away from $x=0$ ) gives

$$
\begin{aligned}
-\int_{\mathrm{I}}^{\mathrm{II}}\left[\frac{u+\{g(1-\lambda) h\}^{1 / 2}}{h_{0}}\right] d h_{0}+\int_{\mathrm{I}}^{\mathrm{II}}\left[\frac{u\{g(1-\lambda) h\}^{1 / 2}}{r}\right] d t & +\left[u_{\mathrm{II}}+2\left\{g(1-\lambda) h_{\mathrm{II}}\right\}^{1 / 2}\right] \\
& -\left[u_{\mathrm{I}}+2\left\{g(1-\lambda) h_{\mathrm{I}}\right\}^{1 / 2}\right]=0
\end{aligned}
$$

along the $\mathrm{C}_{1+}$ characteristic and

$$
\begin{aligned}
-\int_{\mathrm{I}}^{\mathrm{II}}\left[\frac{u-\{g(1-\lambda) h\}^{1 / 2}}{h_{0}}\right] d h_{0}- & \int_{\mathrm{I}}^{\mathrm{II}}\left[\frac{u\{g(1-\lambda) h\}^{1 / 3}}{r}\right] d t \\
& +\left[u_{\mathrm{II}}-2\left\{g(1-\lambda) h_{\mathrm{II}}\right\}^{1 / 3}\right]-\left[u_{\mathrm{I}}-2\left\{g(1-\lambda) h_{\mathrm{I}}\right\}^{1 / 4}\right]=0
\end{aligned}
$$

along the $\mathrm{C}_{1-}$ characteristic. 
It will be seen that in the uncoupled state these become

$$
\int_{\mathrm{I}}^{\mathrm{II}}\left[\frac{u\{g(1-\lambda) h\}^{3 / 2}}{r}\right] d t+\left[u_{\mathrm{II}}+2\left\{g(1-\lambda) h_{\mathrm{II}}\right\}^{* / 3}\right]-\left[u_{\mathrm{I}}+2\left\{g(1-\lambda) h_{\mathrm{I}}\right\}^{3 / 6}\right]=0
$$

along the $\mathrm{C}_{1+}$ characteristic and

$$
-\int_{I}^{\mathrm{II}}\left[\frac{u\{g(1-\lambda) h\}^{1 / 2}}{r}\right] d t+\left[u_{\mathrm{II}}-2\left\{g(1-\lambda) h_{\mathrm{II}}\right\}^{3 / 6}\right]-\left[u_{\mathrm{I}}-2\left\{g(1-\lambda) h_{\mathrm{I}}\right\}^{1 / 2}\right]=0
$$

along the $\mathrm{C}_{1-}$ characteristic.

These latter results can be obtained independently by applying the limit condition to the original equation system, in the same way as for rectilinear flow. The application of these equations in practice will be exemplified with equations (28) which for this purpose may be written in the form

$$
\begin{aligned}
& {\left[u_{\mathrm{II}}+2\left\{g(1-\lambda) h_{\mathrm{II}}\right\}^{3 / 2}\right] \cdots-\left[u_{\mathrm{I}}+2\left\{g(1-\lambda) h_{\mathrm{I}}\right\}^{1 / 2}\right]=-\int_{\mathrm{I}}^{\mathrm{II}}\left[\frac{u\{g(1-\lambda) h\}^{1 / 2}}{r}\right] d t=-\Phi} \\
& {\left[u_{\mathrm{II}}-2\left\{g(1-\lambda) h_{\mathrm{II}}\right\}^{1 / 2}\right]-\left[u_{\mathrm{I}}-2\left\{g(1-\lambda) h_{\mathrm{I}}\right\}^{1 / 2}\right]=+\int_{\mathrm{I}}^{\mathrm{II}}\left[\frac{u\{g(1-\lambda) h\}^{3 / 3}}{r}\right] d t=+\Phi}
\end{aligned}
$$

The significance of these equations can best be demonstrated in the hodograph plane formed by the velocity, $u$, and celerity, $\{g(1-\lambda) h\}^{3 / 3}$ (Fig. 12). In this plane the progress of the surface system from state $I$, at time $t_{1}$, to state II, at time $t_{2}$, will be represented by a motion from points $\mathrm{P}\left(u_{\mathrm{I}}, h_{\mathrm{I}}\right)$ and $\mathrm{P}\left(u_{i}^{\prime} h_{1}^{\prime}\right)$ to another point $\mathrm{P}\left(u_{\mathrm{II}}, h_{\mathrm{II}}\right)$ or, more briefly, from $\mathrm{P}_{\mathrm{I}}, \mathrm{P}_{\mathrm{I}}^{\prime}$ to $\mathrm{P}_{\mathrm{Ir}}$. Now consider a line

$$
\gamma_{+}=u+2\{g(1-\lambda) h\}^{3 / 2}=\text { constant }=\alpha_{I}
$$

drawn through $\mathrm{P}_{\mathrm{I}}$ and a line

$$
\gamma_{+}=u+2\{g(1-\lambda) h\}^{1 / 2}=\text { constant }=\alpha_{\mathrm{II}}
$$

drawn through $\mathrm{P}_{\mathrm{II}}$. The distance between these,

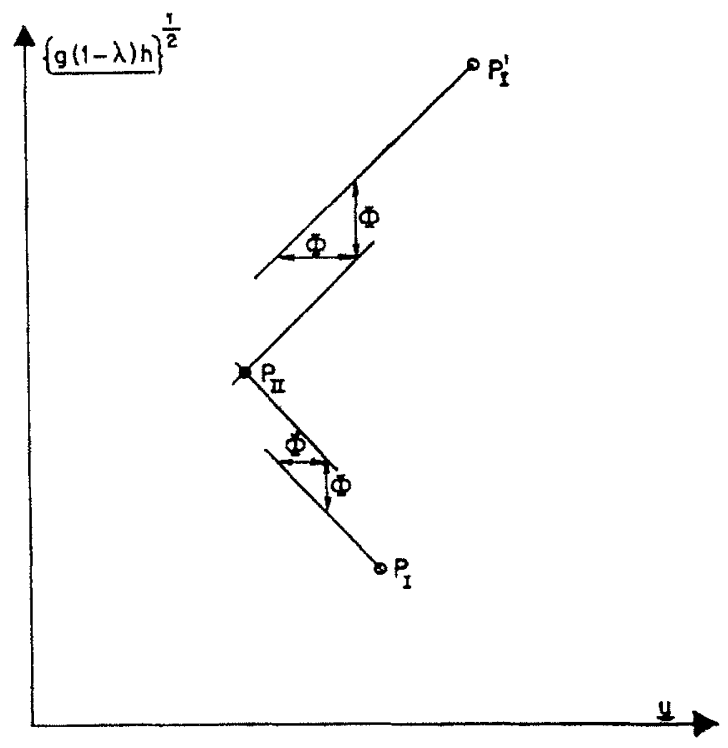

FIG. 12 as measured along a line parallel to the $u$ axis (i.e. horizontally in Fig. 12) is

$$
2\left\{g(1-\lambda) h_{\mathrm{II}}\right\}^{1 / 2}-2\left\{g(1-\lambda) h_{\mathrm{I}}\right\}^{1 / 2}=-\Phi
$$

while along a line parallel to the $\{g(1-\lambda) h\}^{13}$ axis (i.e. vertically in Fig. 12).

$$
u_{\mathrm{II}}-u_{\mathrm{I}}=-\Phi
$$

Thus, in the hodograph plane, a line $\gamma_{+}=\alpha_{I}$ emanating from $P_{I}$ will be translated through a distance (vertical or horizontal) of - $\Phi$ before arriving at a second point $\mathbf{P}_{I I}$, the time taken for this translation, $t_{2}-t_{1}$, being comprehended in the integral - $\Phi$.

Similarly, if a line

$$
\gamma_{-}=u-2\{g(1-\lambda) h\}^{1 / 2}=\mathrm{constant}=\beta_{1}
$$

be drawn through point $\mathrm{P}_{1}^{\prime}$, and a line

$$
\gamma_{-}=u-2\{g(1-\lambda) h\}^{3 / 2}=\mathrm{constan} t=\beta_{\mathrm{II}}
$$

be drawn through $\mathbf{P}_{I I}$, these lines will have a relative displacement, vertically or horizontally, of $+\Phi$.

The above translations, or displacements, are illustrated in Fig. 12, from which it is apparent that, if the velocities are known at any two points, such as $\mathrm{P}_{\mathrm{I}}$ and $\mathrm{P}_{\mathrm{I}}^{\prime}$, then the velocity and celerity at the third point, $\mathrm{P}_{\mathrm{II}}$, can be determined. It will also be clear that there will exist lines joining $\mathrm{P}_{\mathrm{I}}$ and $\mathrm{P}_{\mathrm{II}}, \mathrm{P}_{\mathrm{I}}^{\prime}$ and $\mathrm{P}_{\mathrm{II}}^{\prime}$, which will represent the succession of states experienced by the system, and that these lines will represent the hodograph transformations of the phy- 


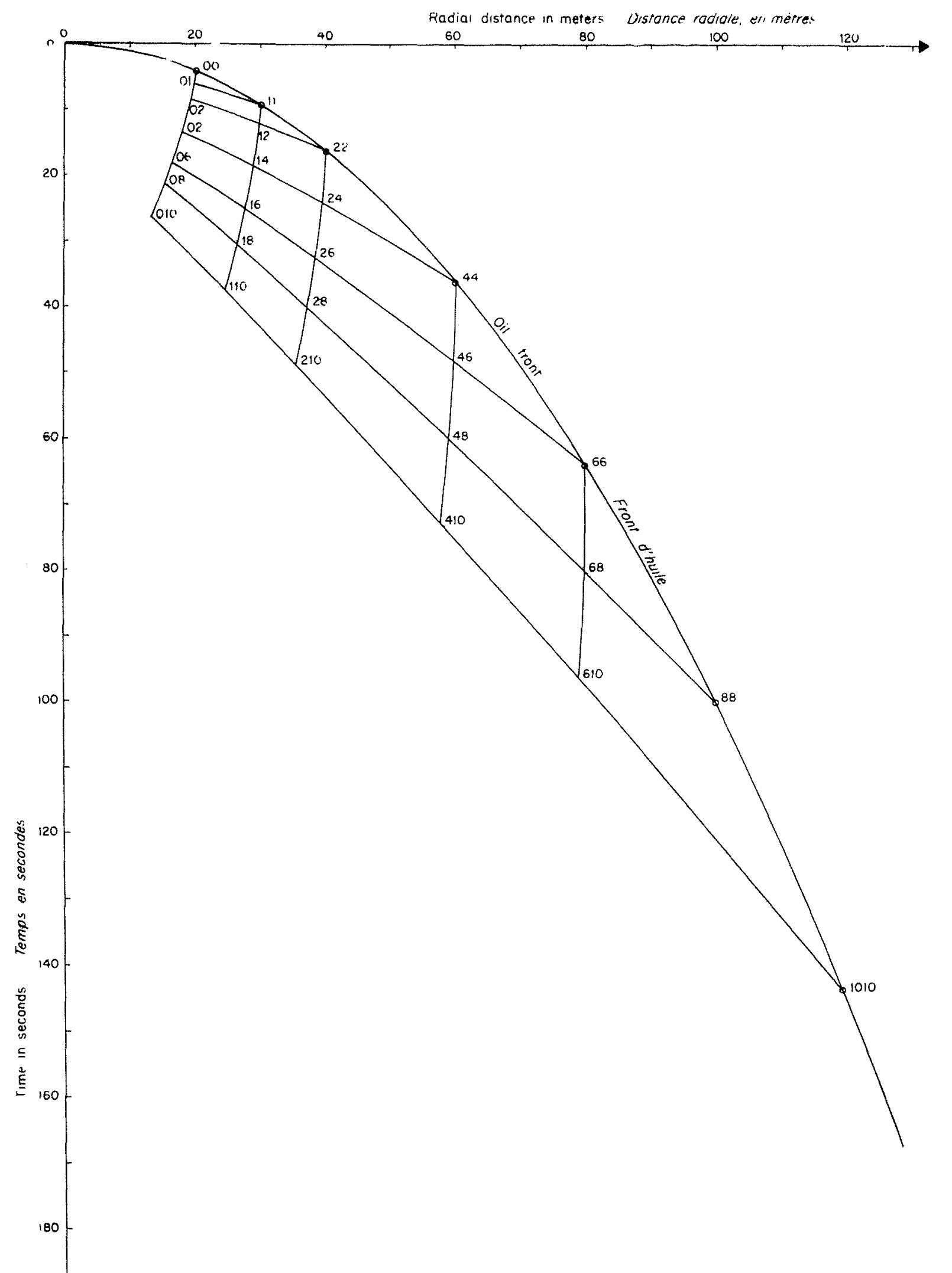

Fic. $13 a$

Physical plane characteristics. Caractéristiques dans le plan physique. 


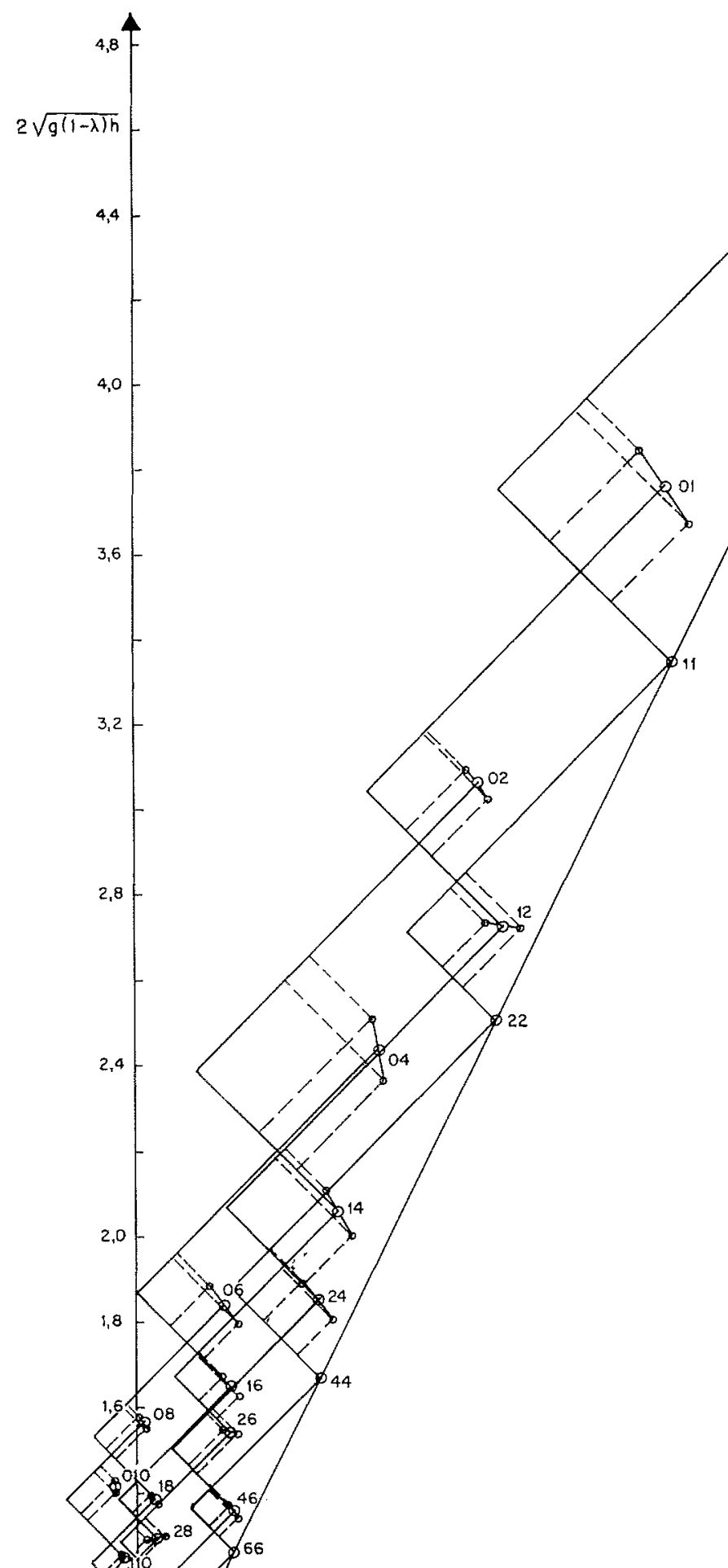

Fig. $13 b$

Hodograph plane characteristics.

Caractéristiques dans le plan de l'hodogramme.

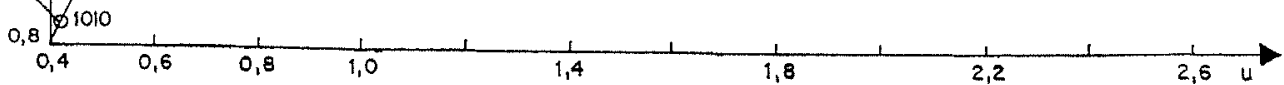


sical characteristics, Such lines are accordingly called the hodograph characteristics (Ref. 3, p. 62).

'The integrands of $\Phi$ over the hodograph characteristics may be taken, to a first approximation, as the values of $u\{g(1-\lambda) h\}^{1 / 2} / r$ obtaining at the initial points $P_{I}$ and $P^{\prime}{ }_{I}$. Then using the above properties of quasi-invariance, the solution surface may be tentatively advanced from points $\mathrm{P}_{Y}, \mathrm{P}^{\prime}$ to point $\mathrm{P}_{\mathrm{II}}$. When trial values of $h, u$ and $r$ have been determined at $P_{I I}$, a second approximation can be made for the integrand of $\Phi$, using the arithmetic means of values at $\mathrm{P}$ and $\mathrm{P}_{\mathrm{II}}, \mathrm{P}^{\prime}$ and $\mathrm{P}^{\prime}{ }_{I I}$, and time intervals from the physical plane. These values may then again be taken as trial values and the process repeated until satisfactory accuracy is attained. Thus, by constructing the physical and hodograph characteristics simultaneously, a solution may be generated from any (non-characteristic) initial line. The physical and hodograph characteristics generated from a typical oil front are shown in Fig. 13, the reason for the particular choice of initial conditions illustrated in Fig. 13 being explained below.

The above procedures may be interpreted physically as means of approximating a diverging flow with a rectilinear one. For large radii and small time intervals the integral $\Phi$ becomes small, while physically the two types of flow become similar. The approximation then consists, in a geometrical sense, of representing the segmental element of the radial flow by the rectangular element appropriate to rectilinear flow. At the origin, however, the segment is essentially a triangle, and thus the approximation breaks down completely there. This situation is represented mathematically by an infinity in the integral $\Phi$ at the origin, $r=0$, i.e. by an infinite displacement of the hodograph characteristics to $u=\infty$. As a result of this singularity at the source, the above method cannot be used to investigate conditions close to the source, but this is not such a serious objection to the method as might at first appear.

It has been noted that,

as

$$
\begin{aligned}
& r \rightarrow 0 \\
& u \rightarrow \infty
\end{aligned}
$$

so that $u h / r$, which occurs in equations (28), is doubly infinite. However, it does not at all follow that $h$ or $\partial h / \partial t$ become infinite at the origin, for, if $u h$ is represented in the form

$$
u h=k r^{-\mathrm{m}}\left(1+\alpha_{1} r+\alpha_{2} r^{2}+\ldots \ldots\right),
$$

where $m$ is positive, so that

$$
u h \rightarrow k r^{-\mathrm{m}} \quad \text { as } r \rightarrow 0,
$$

then, in the limit, $r \rightarrow 0$,

$$
\frac{\partial u h}{\partial r}=-m k r^{-(m+1)}
$$

and

$$
-\frac{u h}{r}=k r^{-(m-1)}
$$

so that $\partial h / \partial t$ represents, in equation (25), the difference of infinities of the same order, and thus may remain finite. Conversely, writting

$\frac{\partial h}{\partial t}=-\left(\frac{\partial u h}{\partial r}+\frac{u h}{r}\right)=--k(1-m) r^{-(m+1)}$,

it follows that, for $\partial h / \partial t$ to remain well behaved as $r \rightarrow 0$, then

as

$$
\begin{aligned}
& r \rightarrow 0 \\
& m \rightarrow 1,
\end{aligned}
$$

Then, again in the limit,

$$
u h=k r^{-1}
$$

or

$$
u h r=k
$$

The term $u h r$ is of course the source strength $q$ mentioned earlier, so that the condition for $\partial h / \partial t$ to be well behaved near the source, is related to the condition that the quantity of flow across successive annuli near the source should be effectively constant.

The above results then suggest that it may be possible to define the fluid behaviour in regions away from the source by the method of characteristics, and to continue the solutions for $h$ and $q$ into the source by a process of extrapolation. The success of such a process will of course depend upon how well the conditions described above are satisfied.

It will thus be seen that, for the flow variables chosen, although it is not possible to find directly the front behaviour corresponding to a given discharge programme, it is possible to determine the discharge programme associated with a given front behaviour. The problem may as well be posed in one way as the other, since it is generally necessary only to determine the relation between the discharge programme and the front condition. Thus the procedure described above represents a means of determining the behaviour of oil flowing radially outward from a source, over water of considerable depth. 


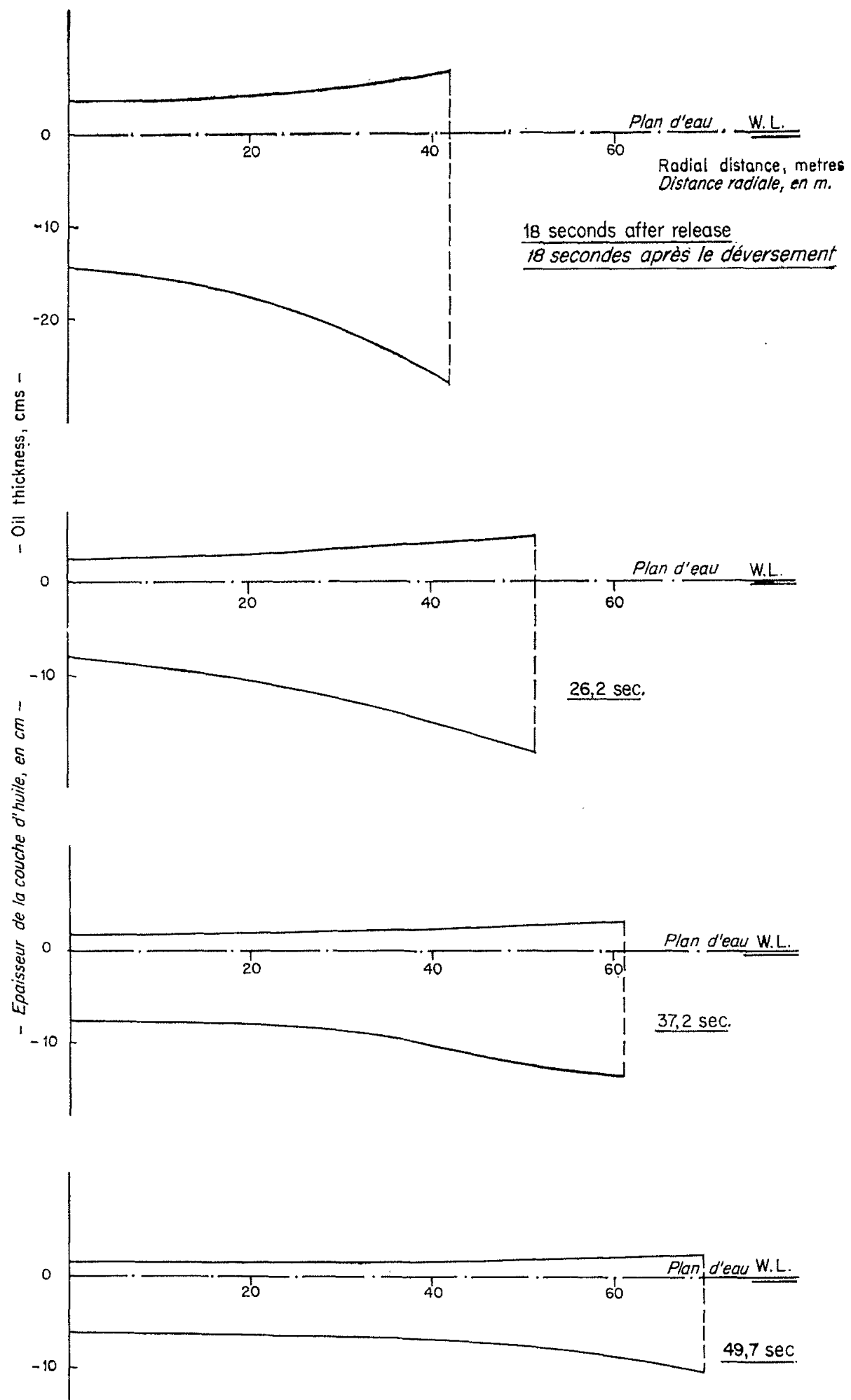

FIG. 14

Oil sections. Sudden release of $1,500 \mathrm{~m}^{8}$ of oil (1,200 tons).

Profils longitudinaux de la couche d'huile.

Déversement soudain de $1500 \mathrm{~m}^{8}$ d'huile (1200 tonnes). 


\section{CONCLUSIONS}

The approach employed above differs considerably from that usually followed in the study of flows with density stratification. This difference in approach arises as a result of differences in the circumstances and objectives of this study as compared with previous studies. So far the fluid flow processes which have received the greatest attention have been those which arise in Oceanography and Meteorology, where the fluid velocities are small compared with the wave celerities, and the differences in density are also small. In these studies the fluid layers may be assumed to be of infinite extent. In the case considered here, on the other hand, the velocities may well be of the same order of magnitude as the wave celerities, and the fluids may differ considerably in density. Moreover the extent of the surface fluid will have an important influence on its behaviour, so that the surface layer certainly cannot be assumed to extend to infinity. There are thus considerable differences between the two viewpoints, but, even so, there remain certain common features, and it will be instructive to try to relate the present work to the more usual approach.

In both of the above sorts of investigation the studies centre around the propagation of long waves through the component layers of a stratified fluid, and the resulting propagation problems are described by hyperbolic partial differential equation systems. Now if the fluid layers are taken to be of infinite extent, the propagation disturbances may be assumed to be periodic in space and time, so that the problem can be posed as one of dynamic equilibrium (in the sense of d'Alembert), and the equation systems made elliptic. Then the solution surfaces of the problems will be analytic everywhere within their boundaries, and the methods of analysis may be applied to determine these solution surfaces. Thus the introduction of this one restriction of periodicity effects a great simplification in the study of the problem, by making it amenable to analysis, and of course it is essentially for this reason that it is introduced.

An even greater simplification of the problem is achieved if the governing (elliptic) equations can be linearised, as then all the theories and methods developed for the study of vibrating strings and membranes may be employed to furnish solutions in terms of simple and transcedental functions. Integral transform and variational methods may further be used to obtain the eigenvalues (e.g. celerities) of the assumed oscillating systems. From this point of view the theorem that coupling separates the natural frequencies becomes indistinguishable from the general theorem that coupling separates the characteristics.

Now in so far as this approach provides the means of acquiring a vast and ready-made mathematical apparatus, it is very convenient, but it is necessary to realise that, as soon as the assumptions upon which it is based cease to be satisfied, then this entire mathematical apparatus fails. Or course many of the features discovered using this approach will not necessarily depend on periodicity and will therefore be true in general, while in many cases the phenomena will be almost linear, so that the answers obtained on the assumptions of linearity may be entirely adequate. Examples of such features are provided by the wave celerity in a deep homogeneous fluid and, to a lesser extent, by the theorem of equipartition of energy. In general, however, the properties of periodic wave motions will not be true for all wave motions (e.g. Ref. 12 p. 33), while in certain cases it may be just the nonlinear effects which are of greatest interest (e.g. in the study of the running hydraulic jump). Thus to take the work considered in this paper, the conditions of periodicity could not possibly be applied to the flow behind the fluid front engendered by the failure of a dam. Similarly, any attempt to linearise equation (1) to (4) by ignoring the flow velocity and neglecting the variations in thickness of the fluid layers would completely alter the nature of the characteristics, and thus the form of the solution.

It will therefore be seen that the analytical methods normally used in the study of stratified flows cannot be justified in the case considered here, whereas, as shown in the text, the use of the "Method of Characteristics," of Riemann and Massau, involves only those restrictions which arise naturally from the realities of the problem. It is for this reason that the Method of Characteristics has been used here for the study of the spreading of one fluid over another. 


\section{ACKNOWLEDGMENTS}

The author is indebted to Dr. I. Torbe, of the University of Southampton, for his guidance and advice in the preparation of the above paper, and to Commander D.H. Macmillan, R.N.R., Hydrographic Surveyor to the Southampton
Harbour Board, who originally suggested this work. The work was carried out in the Civil Engineering Department of the University of Southampton.

\section{BIBLIOGRAPHY}

[1] Rayleigry (J. W. S.). - Theory of Sound, 2nd Edition, 1894. Dover Publications, London, 1945.

[2] LAMB (H.). - Hydrodynamics, 6th Edition, 1932. Cambridge University Press, 1957.

[3] Courant (R.) and Friedrichs (K. O.). - Supersonic Flow and Shock waves, Interscience, 1948.

[4] Keulegan (G.H.). - Chapter XI, Engineering Hydraulics, Chapman and Hall, London, 1950.

[5] Rossby (C. G.). - On the Vertical and Horizontal Concentration of Momentum in Air and Ocean Currents.

Craya (A.). - Critical Regimes of Flows with Density Stratification. Tellus, 3, 1951.

[6] MiLne Thomson (L. M.). - Theoretical Hydrodynamics. Macmillan, London, 1955.

[7] Temple (G.) and Brckley (W. G.). - Rayleigh's Principle. Dover Publications, London, 1956.
[8] Gourd (S. H.). - Variational Methods for Eigenvalue Problems. University of Toronto Press, Toronto, 1957.

[9] Rogard (Y.). - Dynamic Instability. Grosby Lockwood, London, 1957.

[10] Stroker (J. J.). - Water Waves. Interscience, 1957.

[11] Landau and Lifshitz. - Fluid Mechanics. pergammon Press, London, 1955.

[12] Hadamard (J.). - Lectures on Cauchy's Problem (1923). Dover Publications, London, 1952.

[13] YIH (C. S.). - Gravity Waves in a Stratified Fluid. Journal of Fluid Mechanics, Vol. 8, Part 4, 1960.

[14] Aввотт (M. B.). - An Introduction to the Method of Characteristics. International Course in Hydraulic Engineering, Delft, 1960.

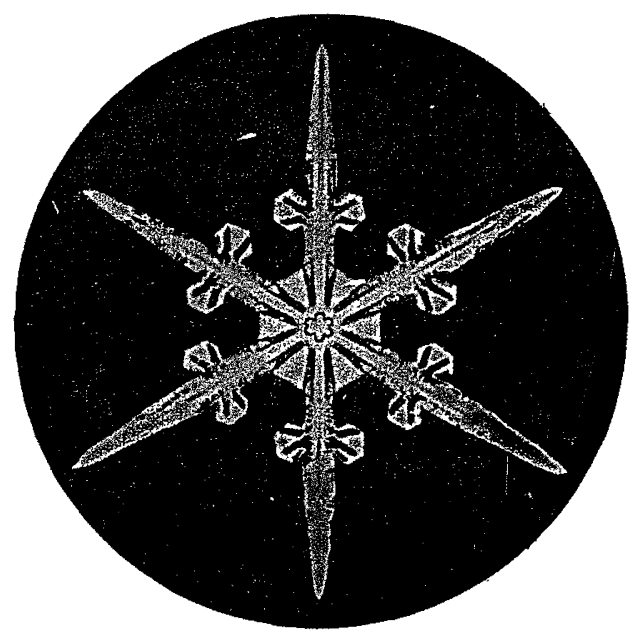




\title{
De l'étalement d'un fluide sur un autre
}

\author{
(Suite et fin) (*) \\ PAR M.B. ABBOTT \\ RESEARCH ENGINEER \\ COASTAL ENGINEERING LABORATORX, TECHNICAL UNIVERSITY OF DENMARI
}

(Voir les illustrations dans le texte anglais, p. 827)

\begin{abstract}
Bien que le présent mémoire traite surtout de l'étalement de l'huile sur l'eau, l'auteur aborde également le problème général de la détermination de la nature et de la vitesse d'étalement d'un fluide incompressible quelconque sur un second fluide, de densité plus élevée. Le mémoire comporte trois parties.
\end{abstract}

\section{PREMIÈRE PARTIE}

Les deux couches fluides sont considérées comme étant les composantes d'un système couplé, et une équation générale est déduite exprimant les caractéristiques de ces couches. L'auteur apporte une nouvelle définition du nombre de degrés de liberté correspondant à un tel système fluide, et met ce nombre en relation avec le pouvoir de propagation d'ondes du système. Il met ensuite en rapport le nombre de caractéristiques d'un système couplé, et le nombre de caractéristiques fluides du même système, et il identifie les deux types de composantes non couplées. Il montre que le couplage provoque la séparation des caractéristiques des composantes, et que le fluide superficiel se comporte comme un système non couplé, lorsque la couche fluide inférieure est beaucoup plus profonde que la couche superficielle. Après un examen des invariants de Riemann et des «quasi-invariants 》de ce système non couplé, l'auteur obtient une mé- thode permettant la résolution des problèmes d'étalement rectiligne.

\section{DEUXIËME PARTIE}

Le problème analogue d'une rupture de barrage est examiné, en introduisant la notion d'un «front d'onde», afin de permettre une meilleure explication du comportement observé au cours des expériences. Le front du fluide superficiel est étudié d'une manière analogue, et les relations existant $\dot{a}$ ce front sont soumises da une noúvelle vérification expérimentale.

\section{TROISIÈME PARTIE}

Les équations et les caractéristiques correspondant $\dot{a}$ un écoulement radial sont déduites, dans cette troisième partie du mémoire. Les caractéristiques sont identiques à celles correspondant $\dot{a}$ un écoulement rectiligne, mais leurs propriétés d'invariance sont différentes.

L'auteur étudie ces propriétés, et élabore une méthode permettant la résolution de problèmes ayant trait à l'écoulement radial d'un fluide sur un autre.

Le mémoire se termine par une comparaison entre la présente étude et des études antérieures sur le même problème.

\section{DEUXIËME PARTIE}

\section{LE FRONT D'ONDE}

Nous avons, jusqu'à présent, seulement considéré l'écoulement d'un fluide sur un autre, pour le cas d'un écoulement établi. Mais, puisque le fluide supérieur ne s'étale qu'à une vitesse finie, il existera en général une région du fluide

$\left(^{\star}\right)$ Cf. La Houille Blanche, ${ }^{\circ}$ 5-1961, page 629. inférieur non encore recouverte par le fluide supérieur $\left(^{\star \star}\right)$.

(**) Ceci ne veut pas dire, bien entendu, que la totalité de cette région découverte n'est pas soumise ḋ l'infiuence $\mathrm{du}$, débit du fluide supérieur. Les mouvements rapides des régimes énergétiques dans le fluide inféricur annonceront la présence du fluide supérieur quelque temps avant que ce dernier n'arrive en réalité. 
Nous appellerons la ligne de séparation entre cette région et celle recouverte par le fluide supérieur le «front fluide». Les aspects particuliers de ce front seront associés, par l'intermédiaire des caractéristiques appropriées, avec l'ensemble de l'écoulement; la description donnée ci-dessus des conditions à l'intérieur de la masse du fluide est donc incomplète en l'absence de connaissances complémentaires des conditions au front fluide. Le présent chapitre examine ces conditions, d'abord sous l'aspect du problème analogue d'un front d'onde créé par la rupture soudaine d'un barrage, et ensuite sous celui des théories de la stabilité hydraulique proposées en premier lieu par Rossby et Craya [5].

\section{La formation d'un front d'onde}

\section{à la suite}

\section{de la rupture brusque d'un barrage}

Les équations de mouvement et de continuité du système superficiel non couplé examiné dans le chapitre précédent deviennent identiques aux équations du mouvement des ondes longues à condition toutefois de remplacer le terme $(1-\lambda)$ $g h$ par le terme $g h$ [p. ex. Réf. 14, Réf. 2, p. 255].

Sur la base de la même substitution, les caractéristiques et les invariants de Riemann deviendront également identiques. A cette seule modification près, on verra que, physiquement, la situation suivant le déversement d'un fluide sur un autre, correspond à celle suivant le déversement d'un fluide sur un fond sec, c'est-à-dire celle provoquée par la rupture soudaine d'un barråge.

D'après la théorie du comportement fluide à la suite de la rupture d'un barrage, telle qu'elle fut avancée en premier lieu par Saint-Venant [Réf. 4, p. 755], les équations auxquelles obéit le mouvement des ondes longues sont admises comme restant valables sur toute la gamme d'écoulement, y compris le front fluide, et ceci à tout instant suivant la rupture du barrage. Les caractéristiques physiques correspondant à cette hypothèse sont représentées par la figure $4 a$ [voir, par exemple, la Réf. 10, p. 333]. Si nous désignons par $\Phi_{u}$ la pente de la caractéristique aval initiale en fonction de l'axe des temps, nous avons :

$$
\Phi_{u}=-\left(g h_{u}\right)^{1 / 2}
$$

d'où, si nous suivons n'importe quelle caractéristique $\mathrm{C}_{+}$, nous voyons que le régime à "l'i-ème » caractéristique $C_{-}$est donné par :

$$
u_{i}+2\left(g h_{i}\right)^{1 / 2}=2\left(g h_{u}\right)^{3 / 2}
$$

ou

$$
u_{i}+2\left(g h_{i}\right)^{3 / s}=-2 \Phi_{u}
$$

Désignons maintenant par $\Phi_{i}$ l'angle renfermé entre, d'une part, l'axe des temps et, d'autre part, « l'i-ième » caractéristique $\mathrm{C}_{-}$, cet angle étant également mesuré dans le sens sinistrorsum (fig. 4 a). Nous avons :

$$
u_{i}-\left(g h_{i}\right)^{1 / 2}=\Phi_{i}
$$

Et, à partir de (13) et (14), il s'ensuit que :

$$
\begin{gathered}
h_{i}=\frac{\left(2 \Phi_{u}-\Phi_{i}\right)^{2}}{9 g} \\
u_{i}=\frac{-2 \Phi_{u}+2 \Phi_{i}}{3} \\
u_{i}+\left(g h_{i}\right)^{3 / 2}=\frac{-4 \Phi_{u}+\Phi_{i}}{3}
\end{gathered}
$$

On voit, d'après (15), qu'au front fluide, où $h_{i}=0$ :

$$
\begin{gathered}
\Phi_{i}=-2 \Phi_{u}=+2\left(g h_{u}\right)^{1 / 2} \\
u_{i}=-\frac{6 \Phi_{u}}{3}=+2\left(g h_{u}\right)^{3 / 3} \\
u_{i}+\left(g h_{i}\right)^{3 / 2}=-\frac{6 \Phi_{u}}{3}=+2\left(g h_{u}\right)^{1 / 2}
\end{gathered}
$$

Le front se compose donc de l'enveloppe caractéristique constituée par la coïncidence des caractéristiques $\mathrm{C}_{+}$et $\mathrm{C}_{-}$, de sorte que la vitesse du front, $u_{f}$, est identique à la célérité de l'onde.

Cependant, ce procédé se heurte à plusieurs objections, dont l'une (d'ailleurs certainement pas l'une des moins importantes) est que les résultats obtenus sont très différents des résultats de: mesures effectuées au voisinage du front 
d'onde. La nature de cette divergence est illustrée, dans la figure 5, par les célèbres données de Schocklitsch [Réf. 4, p. 755]. Ces résultats, ainsi que des observations plus générales suggèrent que le front d'onde se présente en réalité sous l'aspect d'un véritable «mur» d'eau se propageant le long du lit sec. Cependant, aux fins de la présente étude, il suffit de déterminer les relations éventuelles liant la hauteur du front, $h_{f}$, à la vitesse du front, $u_{f}$, et imposées par le front d'onde «en mur », sans s'appesantir sur la structure proprement dite du front.

Afin de préserver la concordance dimensionnelle, nous proposons, pour le front, une relation de la forme :

$$
u_{f}=k\left(g h_{f}\right)^{3 / 2}
$$

Compte tenu de l'aspect physique du phénomène, il paraît admissible d'assimiler un tel front d'onde aux instabilités normales que l'on retrouve dans un fluide homogène, c'est-à-dire à la coïncidence de la vitesse du fluide et de la célérité naturelle de la propagation d'énergie à travers le fluide. Sur la base de cette hypothèse, $k$ prend la valeur de l'unité [voir également la Réf. 6, p. 392]. Le régime d'écoulement ressortant d'une telle hypothèse peut de nouveau être exprimé en fonction de caractéristiques physiques sous-tendant les angles $\Phi_{i}$, et avec une caractéristique amont initiale en $\Phi_{u}$ (fig. $4 b$ ). Toutefois, dans ce cas, la condition de front valable pour tous les $x>0$ (fig. 6), nous donne :

$$
\begin{aligned}
\Phi_{i} & =u_{f}-\left(g h_{f}\right)^{1 / 2} \\
& =0
\end{aligned}
$$

pour toute caractéristique coupant le front. La ligne $x=0$ constitue ainsi une limite de la zone d'onde à centre unique de la théorie de Saint-Venant. Nous avons, à gauche de cette limite (fig. $4 \mathrm{~b}$ ), suivant les caractéristiques $\mathrm{C}_{+}$:

$$
u_{i}+2\left(g h_{i}\right)^{1 / 2}=u_{f}+2\left(g h_{f}\right)^{1 / 2}
$$

et, suivant les caractéristiques $\mathrm{C}_{-}$:

$$
u_{i}-2\left(g h_{i}\right)^{3 / 2}=u_{f}-2\left(g h_{f}\right)^{3 / 2}
$$

de sorte que $u_{i}=u_{f}$, et $h_{i}=h_{f}$, dans la totalité de la région d'écoulement $x>0$. Il existe donc une région à régime constant, à gauche de l'emplacement du barrage, et dans laquelle les quantités d'écoulement restent toujours aux valeurs critiques.

Les résultats ressortant de l'hypothèse suivant laquelle $k=1$, sont représentés par la figure 5, laquelle montre également qu'ils ne s'accordent pas toujours d'une manière entièrement satisfaisante avec les résultats expérimentaux, bien que l'écart soit moindre que celui résultant de la théorie de Saint-Venant.

Il se trouve que l'accord avec les résultats expérimentaux est bien meilleur lorsque $k=2$ (fig. 5), [Réf. 4, p. 756]. Les caractéristiques physiques correspondant à cette condition sont représentées par la figure $4 \mathrm{c}$. On notera que, quelle que soit la valeur de $k$, l'hypothèse d'un front d'onde de la forme (18) implique l'existence d'une région à régime constant derrière ce front, dans laquelle les quantités d'écoulement restent toujours à leurs valeurs critiques. En outre, puisque l'ordonnée $x=0$ est toujours caractéristique, le débit fluide qui la traverse est toujours constant.

Donc, en ce qui concerne l'accord de la théorie avec les données expérimentales, il paraît que le front «enveloppe » de la théorie de SaintVenant et le front dicté par des conditions élémentaires de stabilité ne sont, ni l'un ni l'autre, conformes à ce qui se produit réellement, et qu'une condition intermédiaire semblerait s'assimiler le mieux à la réalité.

\section{Front d'onde naissant dans un fluide comportant des couches superposées de densité différente}

Le front d'onde provoqué par le déversement d'huile sur un plan d'eau est représenté dans les planches (I) et (II). On voit que ce front d'huile comporte très nettement une "tête de front » différente, dans laquelle le régime d'écoulement dans l'huile est effectivement établi, ce qui lui donne une forme analogue à celle du front d'onde engendré par la rupture brusque d'un barrage. Cette analogie, ainsi que celle entre les équations de mouvement correspondant à ces deux cas, laisse penser que la condition du front devrait, en principe, être de la forme :

$$
u_{f}=k\left\{g(1-\lambda) h_{f}\right\}^{1 / 2}
$$

Or, la forme de cette expression est identique à celle de la condition de stabilité, proposée par Rossby et Craya, pour le cas d'un fluide en écoulement sur un deuxième fluide [Réf. 5, p. 5 et 28]. Ces auteurs ont trouvé, en partant de 
considérations d'énergie et de quantité de mouvement, que le régime d'écoulement dans un fluide superficiel peu profond devenait critique lorsque $k=1$. Cependant, l'étude ci-dessus d'un ćcoulement fluide provoqué directement par la rupture d'un barrage montre qu'il est difficile d'établir une équation liant une telle condition de stabilité à une condition de front, et qu'il est nécessaire de déterminer la valeur de $k$ par voie expérimentale. Nous avons donc réalisé deux séries d'expériences pour déterminer cette valeur.

Dans la première série d'expériences, ayant pour objet d'étudier la condition de front, on fit couler de l'eau le long d'un canal uniforme rectiligne de telle manière que de l'huile de paraffine $(\lambda==0,775)$ flottant sur la surface de l'eau se trouvât maintenue contre le volet de réglage du canal (fig. 6). A mesure que l'on augmentait la vitesse d'écoulement de l'eau, la couche d'huile se raccourcissait et s'épaississait toujours davantage, grâce à la condition de front. Ón pouvait alors déterminer directement la valeur de $k$ à l'aide de la relation liant la vitesse de l'eau à l'épaisseur de la couche d'huile.

La figure 7 est la représentation graphique des résultats de ces essais, et on voit que la valeur $k=1,31$ paraît s'accorder le mieux aux observalions. Ces résultats étaient cependant susceptibles d'être faussés considérablement par l'influence de la turbulence (p. ex. planches (I) et (II), et ils ne pouvaient done guère être tenus pour résultats définitifs. Une deuxième série d'expériences, indépendante de la première, a donc été réalisée.

Dans cette deuxième série d'essais, on a introduit un débit uniforme d'huile de paraffine semblable à celle utilisée dans les essais précédents, dans une masse d'eau au repos, l'injection s'effectuant à l'une des extrémités d'un canal rectiligne uniforme, l'autre extrémité du canal étant obturée par une paroi verticale (fig. 8). L'onde d'huile se propageait jusqu'à cette dernière paroi et s'y réfléchissait; l'avancement du front d'onde a été mesuré pendant toute la durée de la propagation.

Les résultats de ces essais sont représentés sur la figure 9, laquelle confronte également les résultats expérimentaux avec des résultats calculés à partir de la valeur $k=1$. La zone de régime constant de ce schéma d'écoulement calculé (Région I sur la figure 9) est identique à celle donnée, pour $k=1$, dans le cas de la rup- ture brusque d'un barrage, car il s'agit cette fois encore d'une source uniforme et d'un régime critique correspondant à des caractéristiques $\mathrm{C}_{-}$ stables dans l'espace. Une onde à centre unique suit cette région, correspondant à l'arrêt soudain de l'écoulement, et représentée par la région II sur la figure 9 . Une deuxième région à régime constant suit cette onde à centre unique (région III), dans laquelle la vitesse est, bien entendu, nulle. Pour le calcul de l'onde réfléchie, il est admis partout que l'énergie potentielle de l'onde réfléchie est équilibrée exactement par le flux d'énergie cinétique du courant incident et relatif au front d'onde réfléchie [Réf. 10, p. 314, Réf. 11, p. 398. ]

L'examen de la figure 9 montre que la valeur $I_{2}=1$ donne, pour l'onde incidente, un bon accord avec les résultats observés. L'onde réfléchie n'est pas aussi bien simulée, bien que l'écart maximal, pour la distance parcourue, reste néanmoins dans les limites de la précision expérimentale. L'accord est manifestement moins satisfaisant pour des valeurs de $k$ autres que l'unité; cette série d'expériences suggère donc la valeur $k=1$.

La différence entre les valeurs de $k$ obtenues dans les deux séries d'expériences peut être attribuée aux différences entre les régimes d'écoulement correspondants. Les planches III et IV montrent le front d'huile correspondant à la deuxième série d'essais; la comparaison entre ce phénomène et celui représenté sur les planches I et II montre que la même forme en «pointe de flèche» du front subsiste dans les deux séries, mais qu'à part cette analogie, les régimes au front sont assez différents d'un cas à l'autre. Compte tenu des différences entre les niveaux turbulents, etc., la deuxième série d'expériences paraît représenter le mieux les conditions réelles, ce qui permet d'admettre, pour $k$, une valeur correspondant approximativement à l'unité. Donc, dans ce cas, les conditions de stabilité et du front coïncident véritablement et :

$$
u_{f}=\left\{g(1-\lambda) h_{f}\right\}^{1 / 2}
$$

Il convient d'ajouter, cependant, que les expériences décrites dans ce qui précède n'ont pu être réalisées que sur une gamme réduite de valeurs des quantités d'écoulement, de sorte que des essais complémentaires seraient sans doute encore à effectuer pour préciser la relation (20). 


\section{TROISIEME PARTIE}

\section{DÉVERSEMENT D'HUILE DANS UNE MASSE D'EAU AU REPOS ÉCOULEMENT RADIAL}

Pour la présente étude de l'étalement plan d'un fluide sur un autre, il sera admis que le fluide superficiel s'étale uniformément à partir d'une source ponctuelle. Dans le cas où la source réelle est située au voisinage d'une paroi (ce qui correspond au cas d'un début de déversement à partir d'un pétrolier), l'ensemble de l'écoulement se produit effectivement à l'intérieur d'un demi-plan. Or, on conçoit aisément qu'un tel demi-plan avec, par exemple, une source, $q$, correspond à un plan entier, dont l'intensité de la source est $2 q$. Or, dans la réalité, l'écoulement provenant d'un pétrolier avarié commencera sous forme d'un écoulement sur un demi-plan, mais tendra de plus en plus à ressembler à un écoulement sur un plan complet, à mesure que la tache d'huile s'étend de plus en plus autour des deux extrémités du bateau (fig. $10 a$ ). Cependant, le schéma se com- plique dans le cas où un courant de marée s'écoule le long du bateau, car un tel courant déformera l'onde d'huile, et l'approximation radiale ne sera plus justifiée (fig. $10 \mathrm{~b}$ ).

Nous décrirons, dans le présent chapitre, l'écoulement radial d'huile sur de l'eau en fonction de deux variables indépendantes, c'està-dire, d'une part, de la distance $r$ de la source d'huile, et d'autre part, du temps $t$ écoulé à partir du début du déversement. Afin de maintenir la conformité avec le cas uni-dimensionnel, nous prendrons, pour nos variables, les profondeurs $h$ et $h_{0}$, et les vitesses $u$ et $u_{0}$, mais nous mesurerons cette fois les vitesses dans le sens radial à partir de la source. Si l'on note que la vitesse de l'huile, $u$, devient infinie à la source on voit aisément que ces variables ne conviennent pas parfaitement. Nous en verrons les conséquences plus loin dans le texte.

\section{Equations et caractéristiques de la propagation radiale}

La figure 11 représente la section et le plan d'un segment du système huile/eau. La pression $p$, subie par un élément d'épaisseur $d z$, situé dans l'huile, à une hauteur arbitrairement choisie $z$, est de nouveau donnée par:

$$
p=p(z, r)=\lambda \rho_{0} g\left(h_{0}+h-z\right)
$$

d'où nous avons, dans l'huile :

$$
\frac{\partial p}{\partial r}=\lambda_{p_{n}} g\left(\frac{\partial h_{0}}{\partial r}+\frac{\partial h}{\partial r}\right)
$$

L'équation de mouvement pour l'élément, situé dans l'huile, peut être déterminée en considérant les forces que subit cet élément. Ces forces sont (fig. 11):

$$
\begin{aligned}
& \mathrm{P}_{1}=\lambda_{\rho_{0}} g\left(h+h_{0}-z\right)+\left(\frac{\partial h_{0}}{\partial r} \frac{d r}{2}+\frac{\partial h}{\partial r} \frac{d r}{2}\right)\left(r+\frac{d r}{2}\right) d z d \theta \\
& \mathrm{P}_{2}=\lambda_{\rho_{0}} g\left(h+h_{0}-z\right)-\left(\frac{\partial h_{0}}{\partial r} \frac{d r}{2}+\frac{\partial h}{\partial r} \frac{d r}{2}\right)\left(r-\frac{d r}{2}\right) d z d 0 \\
& \mathrm{P}_{3}=\lambda \rho_{0} g\left(h+h_{0}-z\right) d r d z
\end{aligned}
$$


D'où la force radiale totale, $\mathrm{P}$, est donnée par :

$$
\mathrm{P}=\lambda_{\vartheta_{0}} g-r\left(\frac{\partial h_{0}}{\partial r}+\frac{\partial h}{\partial r}\right) d r d z d \theta
$$

Le taux de variation de la quantité de mouvement est :

$$
\frac{\partial \mathrm{M}}{\partial t}=\lambda \rho_{0}\left\{\frac{\partial u}{\partial t}+u \frac{\partial u}{\partial r}\right\} r d r d z d \theta
$$

et :

$$
\frac{\partial u}{\partial t}+u \frac{\partial u}{\partial r}+g\left(\frac{\partial h_{0}}{\partial r}+\frac{\partial h}{\partial r}\right)=0
$$

Compte tenu de l'équation de continuité, il appert que le débit net, $d q$, alimentant un élément d'épaisseur $h$, est donné par :

$$
d q=u h r d \theta-\left\{u h r d \theta+\frac{\partial}{\partial r}(u h r d \theta) d r\right\}=\left\{u h+h r \frac{\partial u}{\partial r}+u r \frac{\partial h}{\partial r}\right\} d r d \theta
$$

Le taux de variation volumétrique d'un tel élément est :

$$
d q=\frac{\partial h}{\partial t} r d r d \theta
$$

En égalisant, d'une part, le débit d'alimentation net, et d'autre part, le taux de variation volumétrique de l'élément, on obtient :

$$
\frac{\partial h}{\partial t}+h \frac{\partial u}{\partial r}+u \frac{\partial h}{\partial r}+\frac{u h}{r}=0
$$

Les équations de mouvement et de continuité peuvent être obtenues de la même manière pour le cas où l'élément fluide est situé dans l'eau. Ces équations sont :

$$
\begin{aligned}
& \frac{\partial u_{0}}{\partial t}+u_{0} \frac{\partial u_{0}}{\partial r}+g\left(\frac{\partial h_{0}}{\partial r}+\frac{\partial h}{\partial r}\right)=0 \\
& \frac{\partial h_{0}}{\partial t}+h_{0} \frac{\partial u_{0}}{\partial r}+u_{0} \frac{\partial h_{0}}{\partial r}+\frac{u_{0}}{r} \frac{h_{0}}{r}=0
\end{aligned}
$$

En comparant les équations (21) et (23) aux équations (1) et (3), on voit que les équations de mouvement de l'écoulement radial, et celles de l'écoulement rectiligne, sont de forme identique, parce que les forces du type $P_{3}$ sont équilibrées par une force résiduelle provenant de $P_{1}$ et de $P_{2}$. Les équations sont, comme précédemment, couplées par l'intermédiaire des derniers termes de (21) et (23).

Il appert, des équations (21) à (24), que la forme matricielle de ces équations et de leurs variations sont les mêmes que la matrice correspondant au cas rectiligne, (5), sauf que- $(u h / r)$ et $-\left(u_{0} h_{0} / r\right)$ apparaissent, cette fois, dans le vecteur de la colonne de droite. La condition définissant les caractéristiques, et leurs formes invariantes et quasi invariantes correspondantes, exige de nouveau que la matrice $8 \times 9$ constituée, à la fois à partir du coefficient matriciel et du vecteur de la colonne de droite, soit de rang 7. Etant donné que ni $u h / r$ ni $u_{0} h_{0} / r$ n'interviennent nécessairement dans le déterminant définissant les caractéristiques, ces caractéristiques de l'écoulement radial peuvent être définies exactement de la même manière que celles correspondant à l'écoulement rectiligne.

Ainsi :

$$
\left[(u-\dot{x})^{2}-g h\right]\left[\left(u_{0}-\dot{x}\right)^{2}-g h_{0}\right]-\lambda g^{2} h h_{0}=0
$$

Cette correspondance des caractéristiques, dans des écoulements apparemment si disparates, suit les caractéristiques des ondes correspondant à ces phénomènes, les célérités de propagation en n'importe quel point étant uniquement fonction des quantités d'écoulement en ce même point. Il 
s'ensuit que, pour deux points quelconques, auxquels correspondent des quantités d'écoulement identiques, les célérités elles-mêmes seront identiques, ceci, bìn que ces quantités d'écoulement proviennent d'un type d'écoulement du type donné dans l'un des cas, et d'un type différent dans l'autre. Le type d'écoulement ne peut donc guère affecter les expressions déterminant les caractéristiques. Il s'ensuit, d'une part, que l'on peut définir les caractéristiques des systèmes non couplés d'un écoulement radial de la même manière que ceux correspondant à un écoulement rectiligne, et, d'autre part, que le théorème sur le couplage ne changera pas. Cependant, étant donné que les expressions définissant les propriétés de variation suivant les caractéristiques feront, cette fois, intervenir les termes complémentaires $u h / r$ et $u_{0} h_{0} / r$, ces propriétés de variation ne seront plus les mêmes qu'auparavant.

La nature des variations des quantités d'écoulement suivant les caractéristiques peut être définie de la même manière que pour le cas de l'écoulement rectiligne. En utilisant, suivant la description donnée plus haut, la matrice $8 \times 9$ appropriée, on obtient la condition :

$$
\left|\begin{array}{cccc}
(u-\dot{x}) & g & 0 & -\dot{u} \\
h & (u-\dot{x}) & 0 & -\left(\frac{u h}{r}+\dot{h}\right) \\
0 & g & \left(u_{0}-\dot{x}\right) & \dot{u}_{0} \\
0 & 0 & h_{0} & -\left(\frac{u_{0} h_{0}}{r}+\dot{h_{0}}\right)
\end{array}\right|=0
$$

ou bien :

$$
\left[(u-\dot{x})^{2}-g h\right]\left[\left(\frac{u_{0} h_{0}}{r}+\dot{h}_{0}\right)\left(u_{0}-\dot{x}\right)-h_{0} \dot{u}_{0}\right]-\lambda g h_{0}\left[h \dot{u}-\left(\frac{u h}{r}+\dot{h}\right)(u-\dot{x})\right]=0
$$

En introduisant $\dot{x}=u \pm\{g(1-\lambda) h\}^{1 / 2}$ dans l'équation (25), et en négligeant les quantités de $2^{\mathrm{e}}$ ordre (telles que $u_{0}$, différent de $r=0$ ), on obtient :

$$
\begin{array}{r}
-\int_{\mathrm{I}}^{\mathrm{II}}\left[\frac{u+\{g(1-\lambda) h\}^{1 / 2}}{h_{0}}\right] d h_{0}+\int_{\mathrm{I}}^{\mathrm{II}}\left[\frac{u\{g(1-\lambda) h\}^{1 / 2}}{r}\right] d t+\left[u_{\mathrm{II}}+2\left\{g(1-\lambda) h_{\mathrm{II}}\right\}^{1 / 2}\right] \\
-\left[u_{\mathrm{I}}+2\left\{g(1-\lambda) h_{\mathrm{I}}\right\}^{1 / 2}\right]=0
\end{array}
$$

suivant la caractéristique $\mathrm{C}_{1+}$, et

$$
\begin{aligned}
-\int_{\mathrm{I}}^{\mathrm{II}}\left[\frac{u-\{g(1-\lambda) h\}^{1 / 2}}{h_{0}}\right] d h_{0}-\int_{\mathrm{I}}^{\mathrm{II}}\left[\frac{u\{g(1-\lambda) h\}^{1 / 2}}{r}\right] d t \\
+\left[u_{\mathrm{II}}-2\left\{g(1-\lambda) h_{\mathrm{II}}\right\}^{1 / 2}\right]-\left[u_{\mathrm{I}}-2\left\{g(1-\lambda) h_{\mathrm{I}}\right\}^{1 / 2}\right]=0
\end{aligned}
$$

suivant la caractéristique $\mathrm{C}_{1-}$.

On verra que, dans un état non couplé, ces relations deviennent :

$$
\int_{\mathrm{I}}^{\mathrm{II}}\left[\frac{u\{g(1-\lambda) h\}^{1 / 2}}{r}\right] d t+\left[u_{\mathrm{II}}+2\left\{g(1-\lambda) h_{\mathrm{II}}\right\}^{1 / 2}\right]-\left[u_{\mathrm{I}}+2\left\{g(1-\lambda) h_{\mathrm{I}}\right\}^{1 / 2}\right]=0
$$

suivant la caractéristique $\mathrm{C}_{1+}$, et

$$
-\int_{\mathrm{I}}^{\mathrm{II}}\left[\frac{u\{g(1-\lambda) h\}^{1 / 2}-}{r}\right] d t+\left[u_{\mathrm{II}}-2\left\{g(1-\lambda) h_{\mathrm{II}}\right\}^{1 / 2}\right]-\left[u_{\mathrm{I}}-2\left\{g(1-\lambda) h_{\mathrm{I}}\right\}^{1 / 2}\right]=0
$$

suivant la caractéristique $\mathrm{C}_{1-}$.

Ces derniers résultats peuvent être obtenus indépendamment par application de la condition à la limite au système d'équations original, de la même manière que pour l'écoulement rectiligne. L'application de ces équations dans la pratique sera démontrée à l'aide des équations (28), lesquelles peuvent, à cette fin, être transcrites sous la forme suivante:

$$
\begin{aligned}
& {\left[u_{\mathrm{II}}+2\left\{g(1-\lambda) h_{\mathrm{II}}\right\}^{1 / 2}\right]-\left[u_{\mathrm{I}}+2\left\{g(1-\lambda) h_{\mathrm{I}}\right\}^{1 / 2}\right]=-\int_{\mathrm{I}}^{\mathrm{II}}\left[\frac{u\{g(1-\lambda) h\}^{1 / 2}}{r}\right] d t=-\Phi} \\
& {\left[u_{\mathrm{II}}-2\left\{g(1-\lambda) h_{\mathrm{II}}\right\}^{1 / 2}\right]-\left[u_{\mathrm{I}}-2\left\{g(1-\lambda) h_{\mathrm{I}}\right\}^{1 / 2}\right]=+\int_{\mathrm{I}}^{\mathrm{II}}\left[\frac{u\{g(1-\lambda) h\}^{1 / 2}}{r}\right] d t=+\Phi}
\end{aligned}
$$


C'est sur le plan de l'hodogramme constitué par la vitesse $u$, et par la célérité $\{g(1-\lambda) h\}^{\prime / 3}$ (fig. 12), que la signification de ces équations peut être le mieux mise en évidence. Sur ce plan, l'évolution du système superficiel en partant de l'état I, au temps $t_{1}$, vers l'état II, au temps $t_{2}$, sera représenté par un mouvement prenant son départ des points $\mathrm{P}\left(u_{1}, h_{\uparrow}\right)$ et $\mathrm{P}\left(u_{\mathrm{I}}^{\prime}, h_{\mathrm{I}}^{\prime}\right)$, et se dirigeant vers un troisième point $\mathrm{P}\left(u_{\mathrm{II}}, h_{\mathrm{II}}\right)$, soit plus simplement, allant de $\mathrm{P}_{I}, \mathrm{P}^{\prime}{ }_{I}$ à $\mathrm{P}_{I I}$. Considérons, maintenant, une ligne définie par :

$$
\gamma_{+}=u+2\{g(1-\lambda) h\}^{1 / 2}=\text { Cte }=\alpha_{I}
$$

et passant par $\mathrm{P}_{\mathrm{I}}$, et une ligne définie par :

$$
\gamma_{+}=u+2\{g(1-\lambda) h\}^{1 / 2}=\mathrm{Cte}=\alpha_{\mathrm{II}}
$$

et passant par $\mathrm{P}_{\mathrm{II}}$. La distance entre ces deux lignes, mesurée suivant une ligne parallèle à l'axe u (c'est-à-dire horizontale sur la figure 12) est de :

$$
2\left\{g(1-\lambda) h_{\mathrm{Ir}}\right\}^{1 / 2}-2\left\{g(1-\lambda) h_{\mathrm{I}}\right\}^{1 / 2}=-\Phi
$$

alors que, suivant une ligne parallèle à l'axe $\{g(1-\lambda) h\}^{1 / 2} \quad$ (c'est-à-dire verticale sur la figure 12) :

$$
u_{\mathrm{II}}-u_{\mathrm{I}}=-\Phi
$$

Ainsi, sur le plan de l'hodogramme, une ligne $\gamma_{+}=\alpha_{I}$ émanant de $P_{I}$, sera soumise à une translation sur une distance (verticale ou horizontale) de - $\Phi$ avant d'arriver au deuxième point $\mathrm{P}_{\mathrm{rr}}$, le temps $t_{2}-t_{1}$ nécessité pour cette translation étant inclus dans l'intégrale $-\Phi$.

De même, une ligne définie par :

$$
\gamma_{-}=u-2\{g(1-\lambda) h\}^{1 / 3}=\mathrm{Cte}=\beta_{\mathrm{I}}
$$

et passant par le point $\mathrm{P}_{1}^{\prime}$, et une ligne définie par :

$$
\gamma_{-}=u-2\{g(1-\lambda) h\}^{1 / 2}=\mathrm{Cte}=\beta_{\mathrm{II}}
$$

et passant par $\mathrm{P}^{\prime}{ }_{\mathrm{II}}$, subiraient un déplacement relatif, dans les sens vertical ou horizontal, de $+\Phi$.

Ces translations, ou déplacements, sont représentés sur la figure 12, laquelle montre que, si l'on connaît les vitesses et les célérités en deux points quelconques, tels que $\mathrm{P}_{\mathrm{I}}$ et $\mathrm{P}_{\mathrm{I}}{ }$, on peut alors déterminer la vitesse et la célérité en un troisième point, $P_{I I}$. L'existence de lignes reliant $P_{I}$ à $P_{I I}$ et $P^{\prime}{ }_{I}$ à $P_{I I}$ sera également évidente, lesquelles représenteront, à la fois les divers états successifs du système, et les transformations hodographiques des caractéristiques physiques. De telles lignes sont, par définition, appelées caractéristiques hodographiques [Réf. 3, p. 62].

Les expressions de $\Phi$ à intégrer sur les caractéristiques hodographiques peuvent être admises, en première approximation, comme étant les valeurs de $u\{g(1-\lambda) h\}^{3 / 2} / r$ correspondant aux points initiaux $\mathrm{P}_{\mathrm{I}}$ et $\mathrm{P}_{\mathrm{I}}$. L'utilisation des propriétés de quasi-invariance permet ensuite d'avancer provisoirement la surface de résolution des points $P_{I}, P_{I}^{\prime}$ au point $P_{I I}$. Après avoir déterminé des valeurs d'essai de $h, u$ et $r$, en $\mathrm{P}_{\mathrm{Ir}}$, on peut procéder à une deuxième approximation pour l'intégrand de $\Phi$, en utilisant les moyennes arithmétiques des valeurs en $P_{I}$ et $P_{I I}, P^{\prime}{ }_{i}$ et $P_{I I}$, ainsi que des intervalles de temps du plan physique. Ces valeurs peuvent alors être prises comme nouvelles valeurs d'essai, et ainsi de suite, en répétant le procédé jusqu'à l'obtention d'une précision suffisante. La construction simultanée des caractéristiques physiques et hodographiques permet ainsi d'amener une solution à partir de n'importe quelle ligne initiale (non caractéristique). Les caractéristiques physiques et hodographiques, engendrées à partix d'un front d'huile typique, sont représentées sur la figure 13. La raison déterminant le choix de l'ensemble de conditions de départ correspondant à la figure 13 sera expliquée par la suite.

On peut interpréter, physiquement, les procédés décrits ci-dessus comme constituant un moyen permettant de rapprocher un écoulement divergent d'un écoulement rectiligne. Pour de grands rayons, et de petits intervalles de temps, l'intégrale $\Phi$ devient petite, et, physiquement, les deux types d'écoulement deviennent similaires. L'approximation consiste alors, dans un sens géomètrique, à représenter l'élément segmentaire de l'écoulement radial au moyen de l'élément rectangulaire correspondant à l'écoulement rectiligne. Cependant à l'origine, le segment est, essentiellement, un triangle, de sorte que l'approximation n'est plus du tout valable dans ces conditions. La représentation mathématique de cette situation est une infinité dans l'intégrale $\Phi$ à l'origine, $r=0$, c'est-à-dire un déplacement infini des caractéristiques hodographiques vers $u=\infty$. L'existence de cette singularité à la source exclut l'utilisation de la méthode ci-dessus pour l'étude de conditions au voisinage de la source. Cependant, cet inconvénient est beaucoup moins grave qu'il ne paraît l'être à première vue.

Rappelons que :

$$
\text { Lorsque } \begin{aligned}
r & \rightarrow 0, \\
u & \rightarrow \infty
\end{aligned}
$$

de sorte que $u h / r$, lequel intervient dans les équations (28), est doublement infini. Cependant, il ne s'ensuit guère que $h$, ou $\partial h / \partial t$ deviennent: infinis à l'origine, car, en représentant $u h$ sous la forme :

$u h=k r^{-m}\left(1+\alpha_{1} r+\alpha_{2} r^{2}+\ldots \ldots\right)$, $m$ étant positif, 
de sorte que :

$$
u h \rightarrow k r^{-m} \text { lorsque } r \rightarrow 0,
$$

alors, à la limite, $r \rightarrow 0$ :

$$
\frac{\partial u h}{\partial r}=-m k r^{-(m+1)}
$$

et

$$
\frac{u h}{r}=k r^{-(m-1)},
$$

$\partial h / \partial t$ représente ainsi, dans l'équation (25), la différence d'infinités du même ordre, et peut ainsi rester fini. Au contraire, si nous posons :

$\frac{\partial h}{\partial t}=-\left(\frac{\partial u h}{\partial r}+\frac{u h}{r}\right)=-k(1-m) r^{-(m+1)}$,

il s'ensuit que, pour que le comportement de $\partial h / \partial t$ reste satisfaisant lorsque $r \rightarrow 0$, alors :

$$
\text { Iorsque } \begin{aligned}
& r \rightarrow 0, \\
m & \rightarrow 1
\end{aligned}
$$

Et, de nouveau, à la limite,

soit :

$$
u h=k r^{-1}
$$

$$
u h r=k
$$

Le terme $u h r$ représente évidemment l'intensité de source $q$ à laquelle nous avons fait allu- sion plus haut. La condition nécessaire pour que $\partial h / \partial t$ se comporte de manière satisfaisante au voisinage de la source, est donc liée à la condition que la quantité d'écoulement, à travers des anneaux successifs au voisinage de la source, doit effectivement rester constante.

Ces résultats suggèrent la possibilité de définir le comportement du fluide, dans des zones éloignées de la source, au moyen de la méthode des caractéristiques, et de continuer les solutions pour $h$ et $q$, jusqu'à la source, par un procédé d'extrapolation. La réussite d'un tel procédé dépendra, évidemment, de la mesure dans laquelle les conditions décrites dans ce qui précède seront satisfaites.

On verra donc que, pour les variables d'écoulement choisies, il est possible de déterminer le «programme» d'écoulement correspondant à un comportement donné du front, bien qu'il ne soit pas possible de déterminer directement le comportement d'un front correspondant à un «programme» donné. Le problème peut tout aussi bien se poser d'une manière que de l'autre, car il n'est généralement nćcessaire que de déterminer la relation liant le «programme» d'écoulement à la condition de front. Le procédé décrit ci-dessus représente, ainsi, un moyen permettant de déterminer le comportement d'huile s'écoulant radialement à partir d'une source, au-dessus d'une masse d'eau de profondeur considérable.

\section{CONCLUSIONS}

Le traitement du problème abordé dans la présente étude, est très différent des procédés habituellement employés pour l'étude des écoulements dans des couches à stratification de densité. Cette différence ressort du fait que les circonstances et les objectifs de la présente étude ne sont pas les mêmes que ceux des investigations précédentes. Jusqu'à présent, l'attention s'est fixée principalement sur les écoulements fluides dans les domaines de l'océanographie et de la météorologie, dans lesquels les vitesses fluides sont faibles, par rapport aux célérités des ondes, et les différences de densité sont également peu importantes. Les couches fluides peuvent être considérées comme étant d'une étendue infinie dans de telles études, alors que, dans le présent cas, les vitesses risquent fort d'être du même ordre de grandeur que les célérités d'onde, et il peut exister des différences de densité considérables. De plus, l'étendue du fluide superficiel exercera une influence importante sur son comportement, de sorte que toute hypothèse d'une étendue infinie serait certainement inadmissible. Il se présente donc des différences considérables entre les deux points de rue; cependant, malgré ces différences, il subsiste certains aspects communs aux deux cas, et il sera donc sans doute utile de rechercher un rapport entre la présente étude et le procédé classique.

Dans les deux genres d'investigations évoqués ci-dessus, l'objet essentiel des études est la propagation des ondes longues à travers les couches constituant un fluide stratifié; les problèmes de propagation ainsi posés sont décrits sous forme de systèmes d'équations hyperboliques aux différences partielles. Or, si l'on adnet que l'étendue de ces couches fluides est infinie, on peut également admettre que les perturbations de la propagation sont périodiques, à la fois dans l'espace et dans le temps; ceci permet de poser le problème en tant que problème d'équilibre dynamique (dans le sens donné par d'Alembert), et les systèmes d'équations peuvent être transformés en systèmes d'équations elliptiques. Dans ces conditions. les surfaces de résolution des problèmes seront analytiques en tous les points compris à l'intérieur de leurs limites, 
et la détermination de ces surfaces de résolution pourra s'effectuer à l'aide des méthodes analytiques. L'introduction de cette seule restriction, la périodicité, permet ainsi de simplifier considérablement l'étude du problème, en le rendant adaptable aux méthodes analytiques. C'est d'ailleurs essentiellement pour cette raison que ladite restriction a été introduite.

Ón parvient à simplifier le problème encore davantage si l'on peut réussir à linéariser les équations déterminantes (elliptiques), car ceci permet d'appliquer toutes les méthodes et les théories mises au point pour l'étude des cordes et des membranes vibrantes à la recherche de solutions basées sur les fonctions simples ef transcendantes. Les méthodes de transformation d'intégrales et de variation permettent, en outre, d'obtenir les valeurs propres (par exemple les célérités) des systèmes oscillatoires admis. De ce point de vue, le théorème suivant lequel le couplage sépare les fréquences naturelles se confond avec le théorème général, suivant lequel le couplage sépare les caractéristiques.

L'utilité de cette méthode est qu'elle permet de disposer d'un important appareil mathématique «tout-fait», mais il convient également de noter que l'utilité de cet appareil mathématique se trouve entièrement annulée dès que les hypothèses sur lesquelles la méthode repose ne sont plus satisfaites. Un bon nombre des caractéristiques déterminées au moyen de cette méthode ne dépendront, bien entendu, pas nécessairement de la périodicité; elles seront donc valables dans le sens général, et dans plusieurs autres cas, le phénomène sera presque linéaire, et il se peut que les solutions obtenues dans l'hypothèse d'une loi linéaire soient suffisamment valables. La célérité des ondes dans un fluide homogène profond, ainsi que (mais à un moindre degré) le théorème de l’équirépartition de l'énergie, sont des exemples de telles caractéristiques. Mais, en général, les propriétés des mouvements d'onde périodiques ne pourront guère être généralisées de façon à s'appliquer à tous les mouvements d'ondes [p. ex. Réf. 12, p. 33], alors que dans certains cas, ce seront précisément les phénomènes non linéaires qui présenteront le plus grand intérêt (par exemple dans l'étude du ressaut hydraulique courant). Donc, en ce qui concerne l'étude considérée dans le présent rapport, il serait tout à fait impossible d'appliquer les conditions de périodicité à l'écoulement derrière le front fluide engendré par la rupture d'un barrage. De même, toute tentative tendant à linéariser l'équation (1) à (4), sans tenir compte de la vitesse d'écoulement, et en négligeant les variations de l'épaisseur des couches liquides, modifierait complètement la nature des caractéristiques, et de là, la forme de la solution.

On conçoit donc que les méthodes analytiques utilisées normalement dans l'étude des écoulements stratifiés, ne peuvent se justifier dans le présent cas, alors que, ainsi qu'il a été démontré dans le texte, l'utilisation de la «méthode des caractéristiques » de Riemann et Massau, ne fait intervenir que les restrictions découlant naturellement des réalités du problème. C'est pour cette raison que la méthode des caractéristiques a été utilisée dans la présente étude de l'étalement d'un fluide sur un autre.

\section{REMERCIEMENTS}

L'auteur remercie le Dr. I. Torbe, de l'Université de Southampton, pour son assistance et pour ses conseils pendant l'élaboration du pré sent rapport, ainsi que le commandeur D.H. Macmillan, R.N.R., Ingénieur Hydrographe au- près de l'Administration du port de Southampton, qui lui proposa la présente étude en premier lieu. L'étude a été réalisée au Service du Génie civil de l'Université de Southampton.

\section{BIBLIOGRAPHIE}

[1] Raybeigh (J.W.S.). - Theory of Sound, 2nd Edition, 1894. Dover Publications, London, 1945.

[2] Lamb (H.). - Hydrodynamics, 6th Edition, 1932. Cambridge University Press, 1957.

[3] Courant (R.) et Friedrichs (K. O.). - Supersonic Flow and Shock waves, Interscience, 1948.

[4] Keulegan (G. H.). - Chapter XI, Engineering $\mathrm{Hy}-$ draulics, Chapman and Hall, London, 1950.

[5] Rossby (C. G.). - On the Vertical and Horizontal Concentration of Momentum in Air and Ocean Currents.

Craya (A.). - Critical Regimes of Flows with Density Stratification. Tellus, 3, 1951.

[6] Mirne Thomson (L. M.). - Theoretical Hydrodynamics. Macmillan, London, 1955.

[7] Temple (G.) et Bickley (W. G.). - Rayleigh's Principle. Dover Publications, London, 1956.
[8] Gould (S.H.). - Variational Methods for Eigenvalue Problems. University of Toronto Press, Toronto, 1957.

[9] Rocard (Y.). - Dynamic Instability. Crosby Lockwood, London, 1957.

[10] Stoker (J. J.). - Water Waves. Interscience, 1957.

[11] Landau and Lifshitz. - Fluid Mechanics. Pergammon Press, London, 1955.

[12] Hadamard (J.). - Lectures on Cauchy's Problem (1923). Dover Publications, London, 1952.

[13] YYH (C. S.). - Gravity Waves in a Stratified Fluid. Journal of Fluid Mechanics, Vol. 8, Part 4, 1960.

[14] Аввотт (M. B.). - An Introduction to the Method of Characteristics. International Course in Hydraulic Engineering, Delft, 1960. 